\title{
Silicon pool dynamics and biogenic silica export in the Southern Ocean inferred from Si-isotopes
}

\author{
F. Fripiat ${ }^{1,2}$, A.-J. Cavagna ${ }^{3}$, F. Dehairs ${ }^{3}$, S. Speich ${ }^{4}$, L. André ${ }^{1}$, and D. Cardinal ${ }^{1,{ }^{*}}$ \\ ${ }^{1}$ Section of Mineralogy and Petrography, Royal Museum for Central Africa, Tervuren, Belgium \\ ${ }^{2}$ Department of Earth and Environmental Sciences, Université Libre de Bruxelles, Bruxelles, Belgium \\ ${ }^{3}$ Analytical and Environmental Chemistry \& Earth System Sciences, Vrije Universiteit Brussel, Brussels, Belgium \\ ${ }^{4}$ Laboratoire de Physique des Océans, UMR6523, IFREMER, CNRS, IRD, UBO, Plouzane, France \\ *now at: Laboratoire d'Océanographie et du Climat: Expérimentations et Approches Numériques, \\ Université Pierre \& Marie Curie, Paris, France
}

Received: 8 March 2011 - Published in Ocean Sci. Discuss.: 30 March 2011

Revised: 18 August 2011 - Accepted: 19 August 2011 - Published: 6 September 2011

\begin{abstract}
Silicon isotopic signatures $\left(\delta^{30} \mathrm{Si}\right)$ of water column silicic acid $\left(\mathrm{Si}(\mathrm{OH})_{4}\right)$ were measured in the Southern Ocean, along a meridional transect from South Africa (Subtropical Zone) down to $57^{\circ} \mathrm{S}$ (northern Weddell Gyre). This provides the first reported data of a summer transect across the whole Antarctic Circumpolar Current (ACC). $\delta^{30} \mathrm{Si}$ variations are large in the upper $1000 \mathrm{~m}$, reflecting the effect of the silica pump superimposed upon meridional water transfer across the ACC: the transport of Antarctic surface waters northward by a net Ekman drift and their convergence and mixing with warmer upper-ocean Si-depleted waters to the north. Using $\mathrm{Si}$ isotopic signatures, we determine different mixing interfaces: the Antarctic Surface Water (AASW), the Antarctic Intermediate Water (AAIW), and thermoclines in the low latitude areas. The residual silicic acid concentrations of end-members control the $\delta^{30} \mathrm{Si}$ alteration of the mixing products and with the exception of AASW, all mixing interfaces have a highly Si-depleted mixed layer end-member. These processes deplete the silicic acid AASW concentration northward, across the different interfaces, without significantly changing the AASW $\delta^{30} \mathrm{Si}$ composition. By comparing our new results with a previous study in the Australian sector we show that during the circumpolar transport of the ACC eastward, the $\delta^{30} \mathrm{Si}$ composition of the silicic acid pools is getting slightly, but significantly lighter from the Atlantic to the Australian sectors. This results either from the dissolution of biogenic silica in the deeper layers and/or from an isopycnal mixing with the deep water masses in the different
\end{abstract}

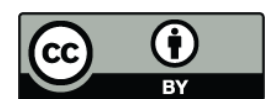

Correspondence to: F. Fripiat (ffripiat@ulb.ac.be) oceanic basins: North Atlantic Deep Water in the Atlantic, and Indian Ocean deep water in the Indo-Australian sector. This isotopic trend is further transmitted to the subsurface waters, representing mixing interfaces between the surface and deeper layers.

Through the use of $\delta^{30} \mathrm{Si}$ constraints, net biogenic silica production (representative of annual export), at the Greenwich Meridian is estimated to be $5.2 \pm 1.3$ and $1.1 \pm$ $0.3 \mathrm{~mol} \mathrm{Si} \mathrm{m}^{-2}$ for the Antarctic Zone and Polar Front Zone, respectively. This is in good agreement with previous estimations. Furthermore, summertime Si-supply into the mixed layer of both zones, via vertical mixing, is estimated to be $1.6 \pm 0.4$ and $0.1 \pm 0.5 \mathrm{~mol} \mathrm{Si} \mathrm{m}^{-2}$, respectively.

\section{Introduction}

In the Southern Ocean, deep nutrient-rich waters ascend into the surface layer and are returned equatorward as subsurface waters, before the available nitrogen pool is fully used by phytoplankton. This contrasts with silicon (in the form of silicic acid, $\mathrm{Si}(\mathrm{OH})_{4}$ ), which is much more depleted by diatom growth and exported along the same pathway (Sarmiento et al., 2004). The Southern Ocean redistributes nutrients at a global scale, thus representing the largest unused nutrient reservoir of the ocean interior and bearing most of the potential to increase the efficiency of the marine biological carbon pump (Sigman et al., 2010). The strong decoupling between nitrogen $(\mathrm{N})$ and silicon $(\mathrm{Si})$ impacts marine productivity at lower latitudes and is due to a complex interplay between, (i) different diatom morphological types presenting varying cellular silicification (Baines et al., 2010),

Published by Copernicus Publications on behalf of the European Geosciences Union. 
(ii) iron and light limitation favouring heavily silicified diatoms (Takeda, 1998; Franck et al., 2003), (iii) the "silicate pump" reflecting the deeper remineralization of Si compared to N (Dugdale et al., 1995; Brzezinski et al., 2003a) and (iv) grazing-induced changes in cell wall silicification as an inducible defence against herbivory (Smetacek et al., 2004; Pondaven et al., 2007; Schultes et al., 2010). The zonal silicic acid gradient is thus controlled by surface water Si uptake by phytoplankton (e.g. diatoms) to form opaline cell walls (referred to as biogenic silica, $\mathrm{bSiO}_{2}$; Pondaven et al., 2000; Brzezinski et al., 2001). At the same time, it is affected by remineralization and physical processes such as vertical mixing, lateral advection and subsequent intermediate water mass formation (Sarmiento et al., 2004, 2007). Deciphering the relative importance of these different processes, which control the nutrient distribution in the Southern Ocean, and understanding how they affect nutrient export to the lower latitudes is necessary to better constrain the role of the Southern Ocean in global biogeochemical cycles of the past, present, and future (Sarmiento et al., 2004; Sigman et al., 2010).

The isotopic composition of silicon $\left(\delta^{30} \mathrm{Si}\right)$ is a valuable tool to help address this point: (i) it integrates longer timescales and larger spatial scales compared to direct flux measurements (e.g. isotope dilution experiments; sediment traps), (ii) it does not manipulate micro-organisms which can induce artefacts, and (iii) the different sensitivities of the mass and isotopic balances in marine systems mean sources can be identified as well as the discrimination between different processes, e.g. $\mathrm{bSiO}_{2}$ production (De La Rocha et al., 1997), $\mathrm{bSiO}_{2}$ dissolution (Demarest et al., 2009), and mixing (Fripiat et al., 2011a). $\mathrm{Si}(\mathrm{OH})_{4}$ uptake by diatoms leaves a clear imprint on the isotopic compositions of both $\mathrm{Si}(\mathrm{OH})_{4}$ and $\mathrm{bSiO}_{2}$. The fractionation factor $\left({ }^{30} \varepsilon=-1.1 \pm 0.4 \%\right.$ o) reported by De La Rocha et al. (1997) seems independent of temperature, species (De La Rocha et al., 1997), cell size (Cardinal et al., 2007) and appears relatively constant across contrasted hydrological environments including fresh water systems (Alleman et al., 2005). By compiling existing data, Fripiat et al. (2011a) estimate an average ${ }^{30} \varepsilon$ for the Antarctic Circumpolar Current (ACC) of $-1.2 \pm 0.2 \%$, a value indistinguishable from in vitro estimates. Biogenic silica dissolution preferentially releases the light $\mathrm{Si}$ isotope, ${ }^{28} \mathrm{Si}$, with a fractionation factor of $-0.55 \%$ o (Demarest et al., 2009). This fractionation is opposite to that occurring during $\mathrm{Si}$ uptake, by about half the absolute magnitude. By increasing the $\mathrm{bSiO}_{2}$ dissolution over production $(D: P)$ ratio, the overall fractionation factor would be dampened (Demarest et al., 2009). Currently, spatial and seasonal coverage of $\delta^{30} \mathrm{Si}$ measurements in the global ocean are limited and additional measurements, controlled experiments and modelling efforts are required to better constrain the origin and fate of the isotopic composition, as well as to better assess modern and past distributions. Indeed, an important application of natural Si-isotopic variability is to track past silicon supply: con- sumption ratios by measuring $\delta^{30} \mathrm{Si}$ of opal accumulating in sediments (De La Rocha et al., 1998; Brzezinski et al., 2002; Beucher et al., 2007).

In this study we present the first complete summer transect of $\delta^{30} \mathrm{Si}_{\mathrm{Si}(\mathrm{OH})_{4}}$ (surface to seafloor) in the different fronts and zones of the Antarctic Circumpolar Current (ACC) and its adjacent subsystems (the SubTropical Zone and the northern part of the Weddell Gyre). The results are discussed in terms of source, pathway, and fate of silicon across the different Southern Ocean water masses and the interaction of the latter with the water masses from other oceanic basins. Results are compared with a similar transect sampled in spring and located in the Australian sector of the Southern Ocean (CLIVAR-SR3; Cardinal et al., 2005). The isotopic constraints allow us to quantify the annual net $\mathrm{bSiO}_{2}$ production and the vertical summertime Si-supply into the mixed layer, both in the Antarctic Zone and Polar Front Zone, using the approach described in Fripiat et al. (2011a). A companion study, Fripiat et al. (2011c), is focused on the origin and fates of $\delta^{30} \mathrm{Si}_{\mathrm{bSiO}_{2}}$ across the whole water column.

\section{Materials and methods}

Between 7 February and 24 March 2008, the International Polar Year (IPY) BONUS-GoodHope (BGH) cruise aboard the R/V Marion Dufresne covered a transect from Cape Town (South Africa) up to $58^{\circ} \mathrm{S}$ in the Southern Ocean roughly centred on the $0^{\circ}$ meridian (Fig. 1a). The general aim of $\mathrm{BGH}$, a GEOTRACES-IPY endorsed project, is to understand the interactions between the physics and biogeochemistry in the Atlantic sector of the Southern Ocean and its exchanges with the Indo-Atlantic connection in the wake of the Agulhas system. Eleven stations were sampled for Siisotopes which were distributed across the different subsystems (Fig. 1a); complete water column profiles ( $\sim 13$ depths per station) were obtained.

Seawater was collected using a CTD (conductivitytemperature-depth) rosette equipped with 121 Niskin bottles. Water samples $(0.25$ to 101$)$ were immediately filtered on Nuclepore polycarbonate membranes $(0.4 \mu \mathrm{m}$ porosity $)$ using Perspex filtration units under the pressure of filtered air ( $<2$ bar). Filtered water samples for silicic acid analysis were stored in acid-cleaned polypropylene (PP) bottles at room temperature in the dark. Potential temperature $(\Theta$, $\left.\mathrm{sd}= \pm 0.0017^{\circ} \mathrm{C}\right)$, salinity $(\mathrm{S}, \mathrm{sd}= \pm 0.0016)$ and dissolved oxygen $\left(\mathrm{O}_{2}, \mathrm{sd}= \pm 2.1 \mu \mathrm{mol} \mathrm{kg}{ }^{-1}\right)$ were recorded using a SBE $911+$ Seabird $^{\circledR} 216$ probe, with respectively, SBE3+, SBE4 and SBE43 sensors (Branellec et al., 2010). Data recording and validation of potential temperature, salinity and oxygen are described by Branellec et al. (2010). 


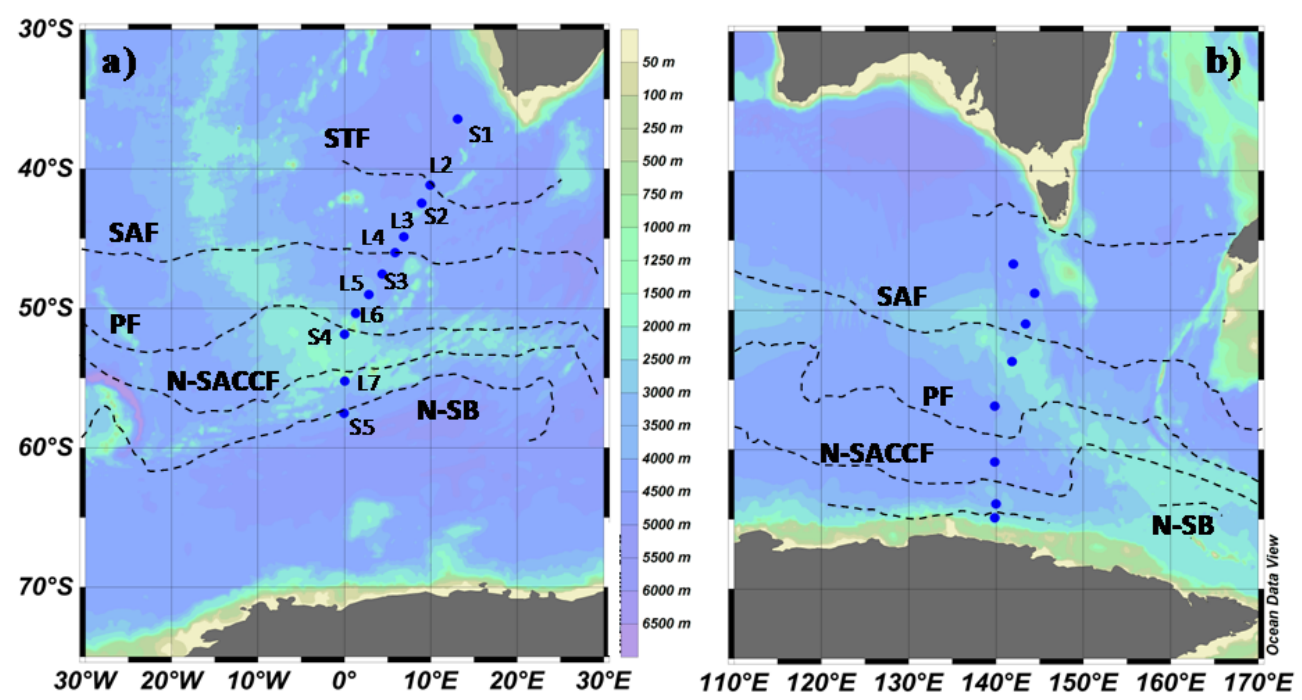

Fig. 1. Map of the BONUS-GoodHope (left panel; February-March 2008) and CLIVAR-SR3 (right panel; October-December 2001) sections with bathymetry and main hydrographic features (following Sokolov and Rintoul, 2009, and Swart et al., 2008; mean path position): $\mathrm{STF}=$ SubTropical Front; SAF = SubAntarctic Front (middle branch); PF = Polar Front (middle branch); N-SACCF = northern branch of the Southern ACC front; N-SB = northern branch of the Southern Boundary. The area north of the STF is referred to as the SubTropical Zone (STZ), between STF and SAF the SubAntarctic Zone (SAZ), between the SAF and PF the Polar Front Zone (PFZ), between the PF and SB the Antarctic Zone (AZ), and south of the SB the Weddell Gyre (WG) on the left side and Seasonal Ice Zone on the right side. S refers to super stations and L to large stations of BGH. Mapping from Ocean Data View (R. Schlitzer, 2003, available at http://odv.awi.de).

\section{Si-analyses}

$\mathrm{Si}(\mathrm{OH})_{4}$ concentrations were measured in duplicate after 28 months via a colorimetric method following a calibration with artificial seawater $\mathrm{Si}(\mathrm{OH})_{4}$ standards (two calibration lines; 0 to $10 \mu \mathrm{moll}^{-1}$ and 0 to $125 \mu \mathrm{moll}^{-1}$; Grasshoff et al., 1983; rsd $<2.5 \%$ ) in the shore-based laboratory on the same samples that were analyzed for $\mathrm{Si}$-isotopic composition. Since $\mathrm{Si}(\mathrm{OH})_{4}$ concentrations of surface and some subsurface waters at stations north of the Polar Front (PF) were too low $\left(<10 \mu \mathrm{moll}^{-1}\right)$ to directly apply the Si purification procedure required for the $\mathrm{Si}$-isotopic measurement (De La Rocha et al., 1996), a $\mathrm{Si}(\mathrm{OH})_{4}$ preconcentration step was performed. The protocol used was adapted from the method described by Brzezinski et al. (2003b) and Reynolds et al. (2006) originally based on the MAGIC method (MAGnesium Induced Coprecipitation; Karl and Tien, 1992). This consisted of a single- (or two-) step scavenging of $\mathrm{Si}(\mathrm{OH})_{4}$ by a brucite $\left(\mathrm{Mg}[\mathrm{OH}]_{2}\right)$ precipitate obtained by increasing the $\mathrm{pH}$ either with $\mathrm{NaOH} 1 \mu \mathrm{moll}^{-1}\left(20 \mathrm{mll}^{-1}\right.$ seawater; Reynolds et al., 2006) or $\mathrm{NH}_{4} \mathrm{OH} 13.5 \mu \mathrm{moll}^{-1}\left(6 \mathrm{ml}^{-1}\right.$ seawater; Brzezinski et al., 2003b). The second scavenging was applied when the Si-recovery during the first step was incomplete. The precipitates were recovered by centrifugation and redissolved with $\mathrm{HCl}$.

Silicon was co-precipitated with triethylamine molybdate (De La Rocha et al., 1996) with a minimum Si requirement of $\sim 1.5 \mu \mathrm{mol}$. After combustion of the silicomolybdate precipitated in covered $\mathrm{Pt}$ crucibles at $1000^{\circ} \mathrm{C}$, the pure cristobalite phase was transferred to pre-cleaned PP vials. Dissolution of cristobalite was done in a dilute $\mathrm{HF} / \mathrm{HCl}$ mixture as described in Cardinal et al. (2003). Isotopic measurements were carried out on a Nu Plasma MCICP-MS (MultiCollector-Inductively Coupled Plasma-Mass Spectrometer; ULB, Brussels) using Mg external doping in dry plasma mode following Abraham et al. (2008). The silicon isotopic compositions are expressed relative to a standard (NBS28) which is analyzed immediately after and before the sample, using the delta value (\%o) as follows:

$\delta^{30} \mathrm{Si}=\left(\frac{\left(\frac{30 \mathrm{Si}}{{ }^{28} \mathrm{Si}}\right)_{\text {sample }}}{\left(\frac{30 \mathrm{Si}}{28 \mathrm{Si}}\right)_{\mathrm{NBS} 28}}-1\right) \cdot 1000$

The average precision and reproducibility of the measurements are $\pm 0.1 \%$ o $( \pm 1 \mathrm{sd})$ for $\delta^{30} \mathrm{Si}$ (Reynolds et al., 2007). The accuracy of the measurements is checked on a daily basis on secondary reference materials (e.g. Diatomite) whose $\mathrm{Si}$-isotopic composition is well known, based on an interlaboratory comparison exercise (Reynolds et al., 2007).

During the CLIVAR-SR 3 cruise along the $145^{\circ} \mathrm{E}$ meridian (ACC; Australian sector; spring; Fig. $1 \mathrm{~b}) \delta^{29} \mathrm{Si}$, by using ${ }^{29} \mathrm{Si}:{ }^{28} \mathrm{Si}$ ratio instead of ${ }^{30} \mathrm{Si}:{ }^{28} \mathrm{Si}$ ratio (Eq. 1), was measured instead of $\delta^{30} \mathrm{Si}$ (Cardinal et al., 2003, 2005), since the method used could not resolve interferences on ${ }^{30} \mathrm{Si}$. To compare with the present $\mathrm{BGH} \delta^{30} \mathrm{Si}$ data, the CLIVAR SR-3 $\delta^{29} \mathrm{Si}$ values were converted to $\delta^{30} \mathrm{Si}$ values using the 

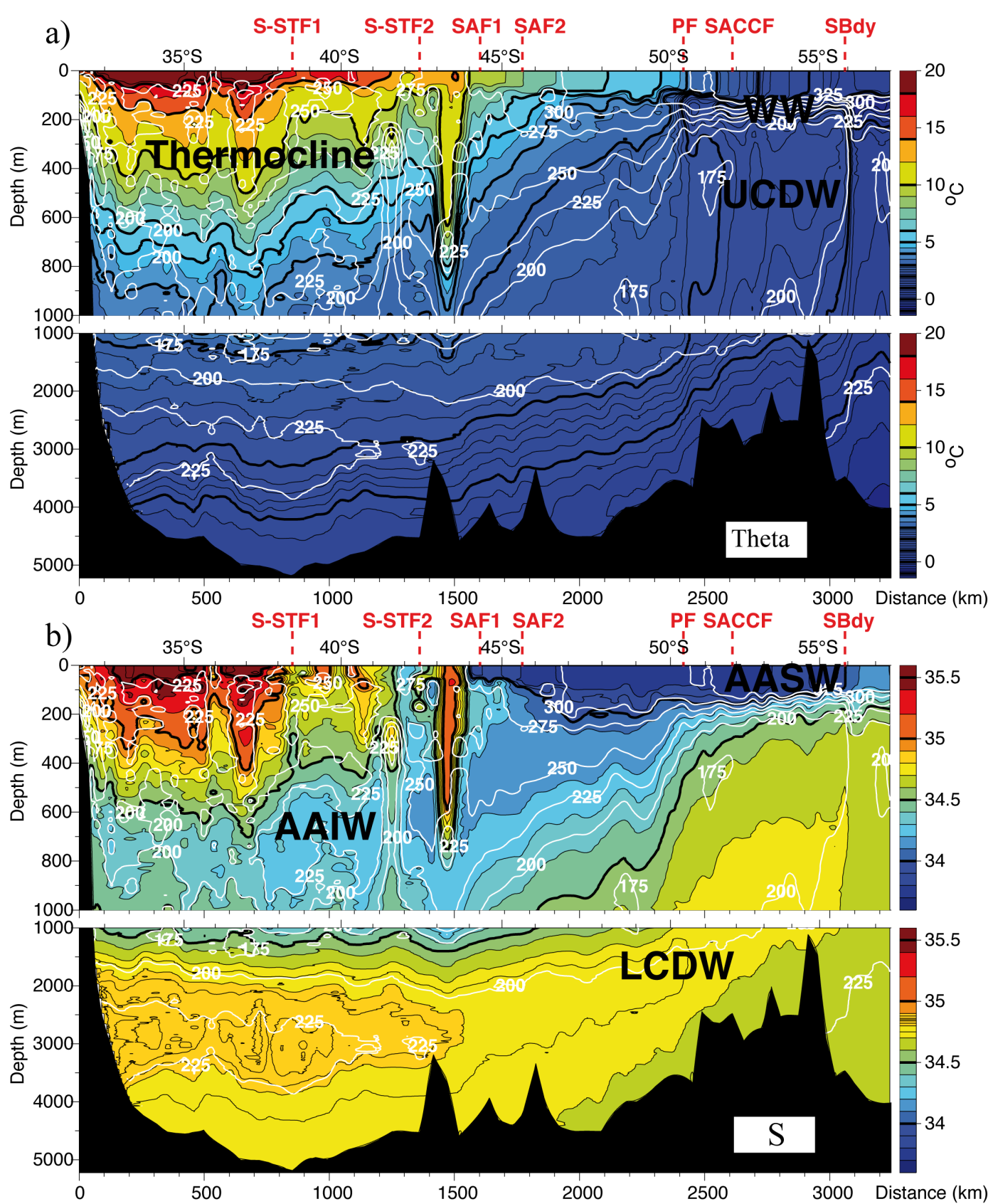

Fig. 2. Interpolation of $\Theta\left({ }^{\circ} \mathrm{C}\right.$, a), salinity (b), both with oxygen contours ( $\mu \mathrm{mol} \mathrm{kg}{ }^{-1}$; white lines) distributions during BONUS-Goodhope (adapted from Speich et al., 2011).

theoretical conversion factor of 1.96 calculated from the kinetic fractionation law (Young et al., 2002).

\section{Results}

In the following discussion, the different water masses are defined by their potential temperature, salinity, and $\mathrm{O}_{2}$ properties (Fig. 2): Upper Circumpolar Deep Water (UCDW; oxygen minimum), Lower Circumpolar Deep Water (LCDW; deep salinity maximum), Antarctic Intermediate
Water (AAIW; subsurface salinity minimum), Winter Water (WW, subsurface temperature minimum), SAZ-STZ thermoclines (between AAIW and the mixed layer, ML), and Antarctic Bottom Water (AABW; bottom increases in $\mathrm{O}_{2}$ content, decreases in temperature and salinity). As some water masses presented asymmetric distribution in both concentration and isotopic composition, the median and the interquartile range $(\cdot 2 / 3$, similar to $1 \mathrm{sd})$ has been chosen as metric for the "central values" and dispersion for the different water masses. 
Table 1. $\mathrm{Si}(\mathrm{OH})_{4}$ concentration and isotopic composition. Only the standard deviations of samples replicated are provided. The solid lines represent the mixed layer depth.

\begin{tabular}{|c|c|c|c|c|}
\hline Station & $\begin{array}{l}\text { Depth } \\
\mathrm{m}\end{array}$ & $\begin{array}{c}\mathrm{Si}(\mathrm{OH})_{4} \\
\mu_{\mathrm{mol}} 1^{-1}\end{array}$ & $\begin{array}{c}\delta^{30} \mathrm{Si}_{\mathrm{Si}(\mathrm{OH})_{4}} \\
\% 0\end{array}$ & $\begin{array}{l}\mathrm{sd} \\
\% o\end{array}$ \\
\hline Super 5 & 29 & 65.2 & 1.85 & 0.00 \\
\hline 16 March 2008 & 88 & 64.2 & 2.00 & \\
\hline \multirow[t]{13}{*}{$00.02^{\circ} \mathrm{E}-57.32^{\circ} \mathrm{S}$} & 151 & 84.1 & 1.50 & 0.03 \\
\hline & 199 & 96.2 & 1.35 & 0.01 \\
\hline & 251 & 101.5 & 1.37 & 0.05 \\
\hline & 299 & 104.2 & 1.41 & 0.05 \\
\hline & 400 & 110.5 & 1.44 & 0.36 \\
\hline & 499 & 117.2 & 1.47 & \\
\hline & 700 & 116.5 & 1.44 & 0.20 \\
\hline & 1003 & 120.0 & 1.27 & \\
\hline & 1499 & 119.1 & 1.13 & \\
\hline & 1999 & 116.6 & 1.12 & 0.06 \\
\hline & 2500 & 119.7 & 1.43 & \\
\hline & 3000 & 117.2 & 1.11 & 0.08 \\
\hline & 3979 & 118.8 & 1.08 & \\
\hline Large 7 & 4 & 50.7 & 1.95 & \\
\hline 14 March 2008 & 80 & 50.0 & 1.78 & 0.07 \\
\hline \multirow[t]{8}{*}{$00.03^{\circ} \mathrm{E}-55.14^{\circ} \mathrm{S}$} & 100 & 58.9 & 1.77 & 0.11 \\
\hline & 149 & 74.4 & 1.54 & \\
\hline & 199 & 79.7 & 1.53 & 0.17 \\
\hline & 300 & 86.5 & 1.61 & \\
\hline & 600 & 93.9 & 1.25 & 0.08 \\
\hline & 1002 & 103.5 & 1.34 & \\
\hline & 2096 & 122.7 & 1.38 & \\
\hline & 2768 & 129.2 & 1.43 & 0.03 \\
\hline Super 4 & 11 & 22.2 & 2.42 & \\
\hline 11 March 2008 & 79 & 22.3 & 2.37 & 0.06 \\
\hline \multirow[t]{11}{*}{$00.00^{\circ} \mathrm{E}-51.87^{\circ} \mathrm{S}$} & 100 & 21.9 & 2.16 & 0.08 \\
\hline & 149 & 30.5 & 2.03 & \\
\hline & 199 & 63.2 & 1.48 & 0.00 \\
\hline & 300 & 86.0 & 1.41 & 0.09 \\
\hline & 398 & 87.6 & 1.58 & 0.17 \\
\hline & 553 & 88.9 & 1.37 & 0.16 \\
\hline & 704 & 90.1 & 1.53 & \\
\hline & 1201 & 101.9 & 1.35 & \\
\hline & 1601 & 109.5 & 1.47 & \\
\hline & 2001 & 121.6 & 1.30 & \\
\hline & 2551 & 131.2 & 1.13 & \\
\hline
\end{tabular}

In the mixed layer, $\delta^{30} \mathrm{Si}_{\mathrm{Si}(\mathrm{OH})_{4}}$ and $\mathrm{Si}(\mathrm{OH})_{4}$ concentrations displayed an inverse pattern with latitude (Table 1; Fig. 3a, b). ${ }^{30} \mathrm{Si}$ enrichment was associated with a decrease in $\mathrm{Si}(\mathrm{OH})_{4}$ concentration from south to north, as also reported in earlier studies (Varela et al., 2004; Cardinal et al., 2005). This condition is mainly driven by the preferential uptake of ${ }^{28} \mathrm{Si}$ by diatoms (De La Rocha et al., 1997) along the northward advection of surface waters (Varela et al., 2004) followed by diatom export out of the mixed layer. This
Table 1. Continued.

\begin{tabular}{|c|c|c|c|c|}
\hline Station & $\begin{array}{l}\text { Depth } \\
\mathrm{m}\end{array}$ & $\begin{array}{c}\mathrm{Si}(\mathrm{OH})_{4} \\
\mu_{\mathrm{mol}} 1^{-1}\end{array}$ & $\begin{array}{c}\delta^{30} \mathrm{Si}_{\mathrm{Si}(\mathrm{OH})_{4}} \\
{ }_{00}\end{array}$ & $\begin{array}{l}\mathrm{sd} \\
\% o\end{array}$ \\
\hline \multirow{15}{*}{$\begin{array}{l}\text { Large } 6 \\
8 \text { March } 2008 \\
01.18^{\circ} \mathrm{E}-50.22^{\circ} \mathrm{S}\end{array}$} & 3 & 4.0 & 2.47 & \\
\hline & 48 & 4.0 & 2.48 & \\
\hline & 98 & 5.1 & 2.47 & \\
\hline & 129 & 20.1 & 2.03 & \\
\hline & 200 & 41.3 & 2.04 & \\
\hline & 251 & 48.2 & 1.57 & 0.15 \\
\hline & 401 & 64.4 & 1.42 & 0.13 \\
\hline & 602 & 75.7 & 1.39 & \\
\hline & 801 & 79.3 & 1.46 & \\
\hline & 999 & 79.1 & 1.37 & 0.15 \\
\hline & 1501 & 78.4 & 1.44 & \\
\hline & 2002 & 93.1 & 1.28 & \\
\hline & 2500 & 115.4 & 1.36 & \\
\hline & 2998 & 124.7 & 1.38 & \\
\hline & 3596 & 125.9 & 1.62 & \\
\hline \multirow{13}{*}{$\begin{array}{l}\text { Large } 5 \\
7 \text { March } 2008 \\
02.50^{\circ} \mathrm{E}-49.02^{\circ} \mathrm{S}\end{array}$} & 9 & 1.8 & 2.77 & \\
\hline & 70 & 1.9 & 2.84 & 0.08 \\
\hline & 100 & 2.0 & 1.99 & 0.03 \\
\hline & 151 & 7.2 & 2.07 & \\
\hline & 200 & 13.8 & 1.92 & \\
\hline & 300 & 22.4 & 1.36 & \\
\hline & 402 & 30.9 & 1.99 & 0.28 \\
\hline & 600 & 44.6 & 1.63 & \\
\hline & 799 & 65.6 & 1.53 & 0.01 \\
\hline & 1000 & 68.2 & 1.58 & \\
\hline & 2001 & 76.2 & 1.41 & \\
\hline & 3001 & 105.7 & 1.37 & \\
\hline & 4080 & 128.6 & 1.44 & \\
\hline \multirow{16}{*}{$\begin{array}{l}\text { Super } 3 \\
6 \text { March } 2008 \\
04.23^{\circ} \mathrm{E}-47.33^{\circ} \mathrm{S}\end{array}$} & 5 & 2.1 & 3.24 & 0.01 \\
\hline & 41 & 2.1 & 2.85 & \\
\hline & 79 & 2.2 & 2.36 & \\
\hline & 100 & 4.2 & 2.57 & 0.19 \\
\hline & 149 & 9.2 & 2.30 & \\
\hline & 200 & 10.4 & 2.42 & \\
\hline & 401 & 25.3 & 1.93 & 0.35 \\
\hline & 600 & 42.5 & 1.67 & \\
\hline & 1002 & 67.8 & 1.43 & \\
\hline & 1403 & 70.0 & 1.42 & \\
\hline & 2000 & 76.6 & 1.34 & \\
\hline & 2301 & 85.6 & 1.26 & 0.01 \\
\hline & 2900 & 101.8 & 1.39 & 0.34 \\
\hline & 3500 & 116.0 & 1.16 & \\
\hline & 4101 & 122.6 & 1.37 & \\
\hline & 4532 & 132.1 & 1.28 & \\
\hline
\end{tabular}

study reveals heavier summer surface $\delta^{30} \mathrm{Si}_{\mathrm{Si}(\mathrm{OH})_{4}}$ signatures in agreement with an increased seasonal $\mathrm{Si}(\mathrm{OH})_{4}$ depletion (Fig. 3) relative to spring results (Cardinal et al., 2005), for two different ACC transects (Australian and Atlantic sectors, respectively, Fig. 1). 
Table 1. Continued.

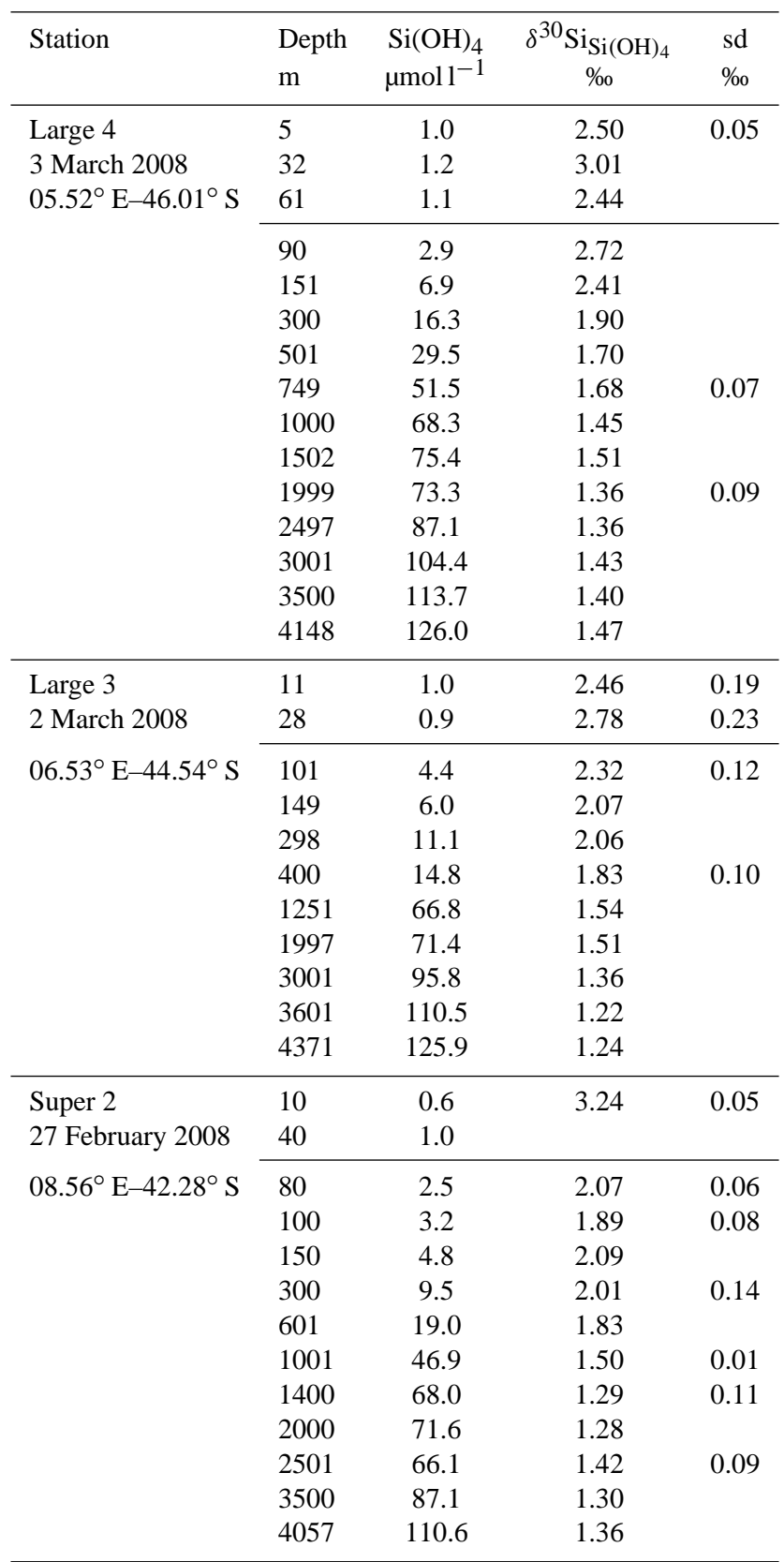

Most of the $\delta^{30} \mathrm{Si}_{\mathrm{Si}(\mathrm{OH})_{4}}$ variation across the BONUSGoodHope transect was limited to the upper $1000 \mathrm{~m}$, with a clear north-south gradient showing heavier Si-isotopic values equatorward associated with a decrease in $\left[\mathrm{Si}(\mathrm{OH})_{4}\right]$ (Figs. 3 and 4). Although the isotopic variation below $1000 \mathrm{~m}$ was small, there was still a slight decrease in values of $\delta^{30} \mathrm{Si}_{\mathrm{Si}(\mathrm{OH})_{4}}$ coincident with increasing $\mathrm{Si}(\mathrm{OH})_{4}$ concentrations (Fig. 4), as reported also by Cardinal et al. (2005) and Fripiat et al. (2011a). The Upper Circumpolar Deep Water (UCDW) had a slightly heavier $\delta^{30} \mathrm{Si}_{\mathrm{Si}(\mathrm{OH})_{4}}$ signature and a
Table 1. Continued.

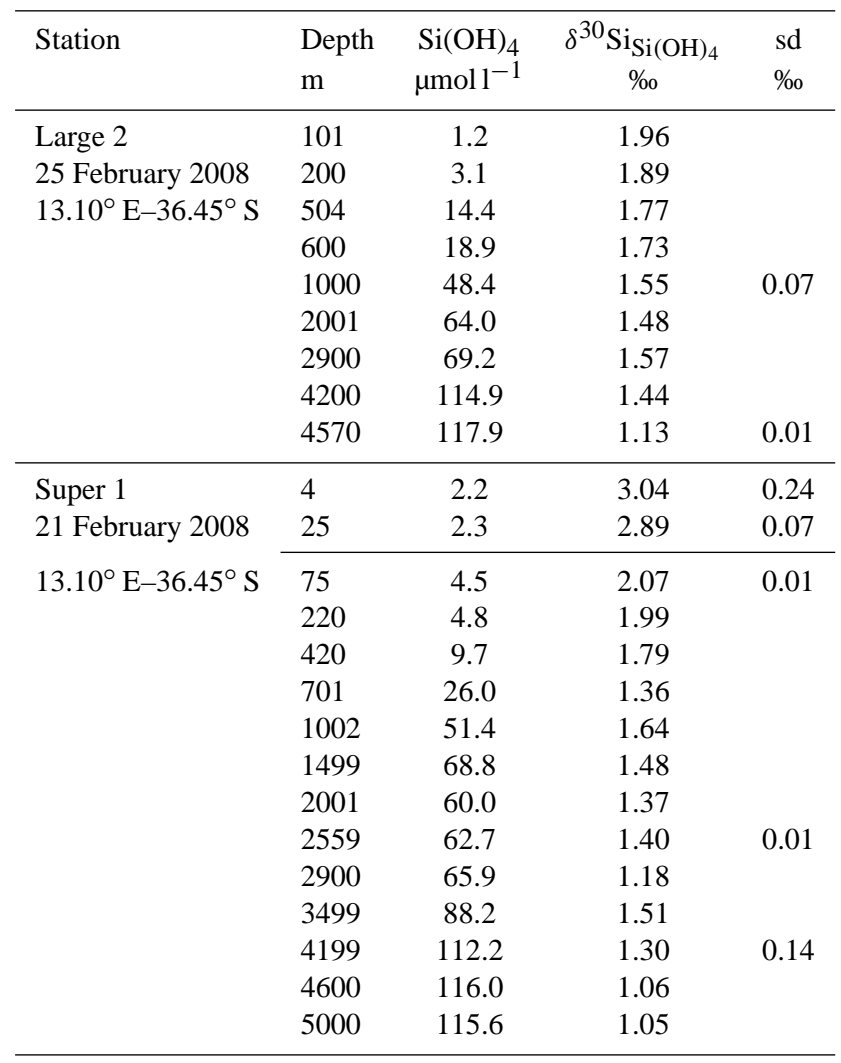

lower $\mathrm{Si}(\mathrm{OH})_{4}$ concentration than Lower Circumpolar Deep Water (LCDW) and Antarctic Bottom Water (AABW).

\section{Discussion}

\subsection{General considerations}

In the following discussion, we will follow the silicon pathway and the transformations encountered along the meridional as well as the circumpolar circulations of the ACC. The ACC represents the largest mass transport of all ocean currents, a slab of water more than $2000 \mathrm{~m}$ thick moving eastward (Tomczak and Godfrey, 2001), but mainly centered in several jets along frontal systems: the inner ACC fronts (Sokolov and Rintoul, 2009); SubAntarctic Front, Antarctic Polar Front, Southern ACC Front. The ACC fronts represent almost impermeable barriers, delimiting zones with relatively constant hydrological and biogeochemical properties (Sokolov and Rintoul, 2007) although cross frontal exchanges do occur locally, associated with sharp topographic features. This wind-driven meridional ACC circulation is characterised by: (1) the shoaling of deeper isopycnal surfaces (UCDW and LCDW) in the Southern ACC towards the Antarctic divergence (Fig. 2; Pollard et al., 2002, 2006), 

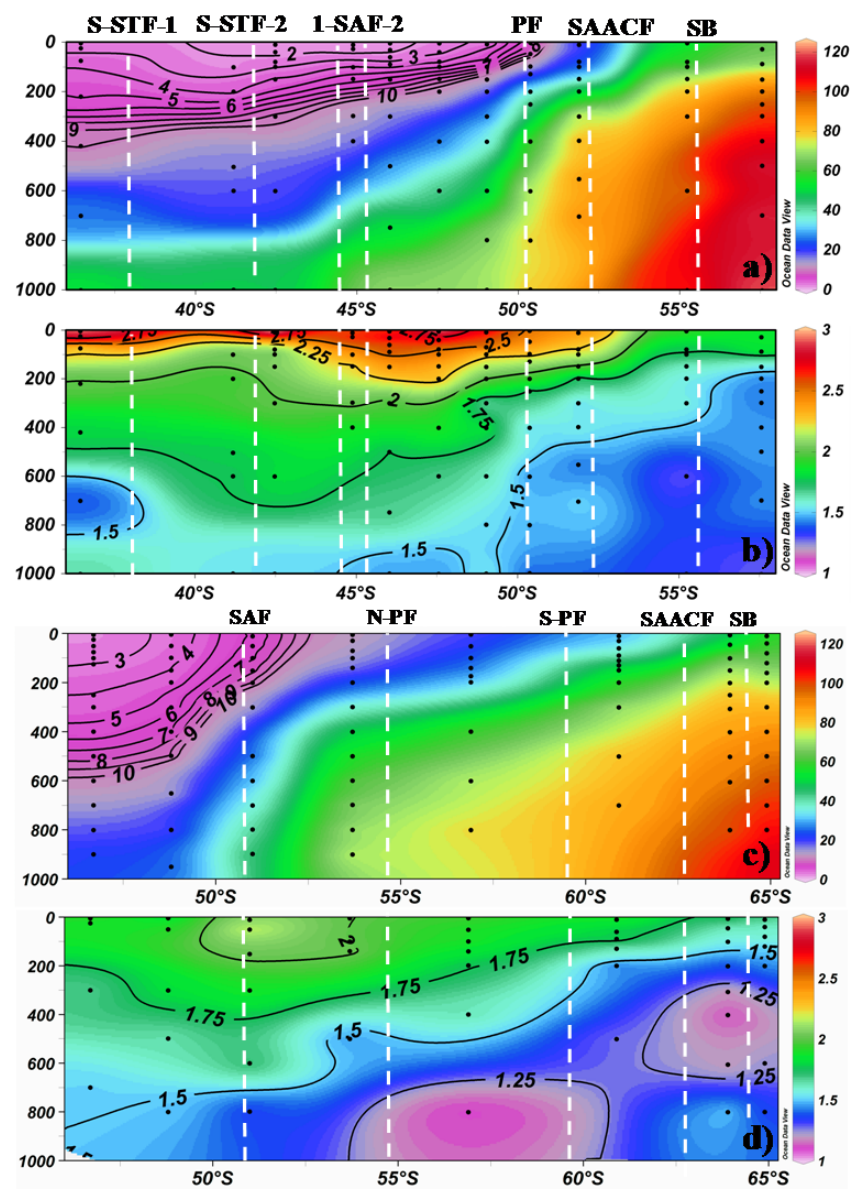

Fig. 3. Interpolation of $\delta^{30} \mathrm{Si}(\mathbf{b}, \mathbf{d})$ and $\left[\mathrm{Si}(\mathrm{OH})_{4}\right](\mathbf{a}, \mathbf{c})$ distributions in the upper $1000 \mathrm{~m}$ during BONUS-GoodHope (this study; a, b) and CLIVAR-SR3 ( $145^{\circ} \mathrm{E}$; c, d; from Cardinal et al., 2005). Interpolation is from Ocean Data View (R. Schlitzer, 2003, available at http://odv.awi.de). The positions of the fronts from Speich et al. (2011) at the time of sampling are also shown (dashed white lines).

(2) part of the upwelled CDW losing buoyancy near Antarctica to form AABW (Orsi et al., 1999) and the remaining gaining buoyancy and being advected northward (Antarctic Surface Water, AASW) via Ekman pumping (Fig. 2; Sloyan and Rintoul, 2001; Pollard et al., 2002), (3) the subsequent formation of intermediate water masses taking place (AAIW, and SubAntarctic Mode Water, SAMW), spreading and deepening northward of the PF (Fig. 2: Sarmiento et al., 2004). The latitudinal $\delta^{30} \mathrm{Si}$ variation in the water column follows this meridional circulation (Figs. 3 and 4).

During the BGH which took place in late summer 2008, the measured silicon properties of the mixed layer can be considered as representative of final summer conditions. This is supported by (i) a Si-uptake in the mixed layer in the lower range of published values, $0.02 \pm 0.03 \mu \mathrm{mol} \mathrm{Si} l^{-1} \mathrm{~d}^{-1}$ (mean Si-uptake from ${ }^{30} \mathrm{Si}$ tracer incubations for the $\mathrm{BGH}$ transect, $n=27$ triplicates), accounting only for $0.6 \pm 0.9 \%$
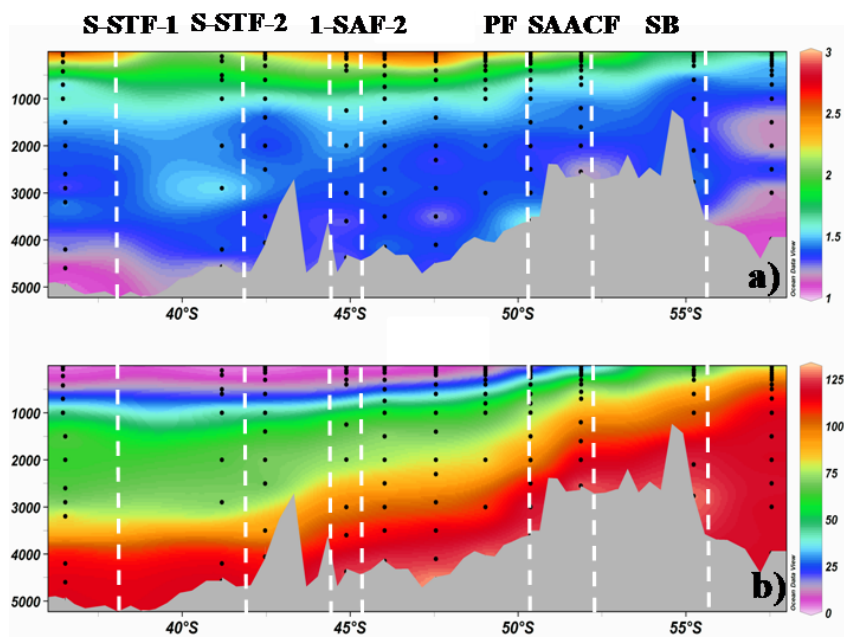

Fig. 4. Interpolation of $\delta^{30} \mathrm{Si}$ (a) and $\left[\mathrm{Si}(\mathrm{OH})_{4}\right]$ (b) distributions for the complete water column during BONUS-GoodHope. Interpolation is from Ocean Data View (R. Schlitzer, 2003, available at http://odv.awi.de). The positions of the fronts at the time of sampling (Speich et al., 2011) are shown as dashed white lines.

of the available silicic acid concentration (Fripiat, 2010), and (ii) satellite $\mathrm{Chl}-a / \mathrm{POC}$ data indicating that the main productive period in the area occurred roughly in December (Moore and Abbot, 2000; Allison et al., 2010).

\subsection{Isotopic constraints on the silicic acid leakage from the Southern Ocean to the low latitude areas}

\subsubsection{Southern ACC}

We define the southern ACC as the area south of the Polar Front where isopycnal surfaces shoal and UCDW and LCDW upwell near the surface (Fig. 2). From Fig. 5a, it is apparent that the subsurface waters (WW and UCDW) in the southern ACC are mixing interfaces between LCDW and AZ mixed layers. Indeed, both AZ-PF Winter Water (WW) and UCDW fit well on a mixing curve with the AZ-PF mixed layer and the LCDW as end-members, in agreement with our observations for the Indian sector of the Southern Ocean (Fripiat et al., 2011a). The UCDW and AZ-PF mixed layers generate a homogeneous deep mixed layer at the onset of winter convective mixing: Antarctic Surface Water (AASW; Park et al., 1998). Due to surface warming in the summer, Antarctic Surface Water stratifies into an upper ML and a lower WW, with the latter maintaining the original AASW characteristics (Pondaven et al., 2000a; Altabet and François, 2001; Fripiat et al., 2011a; Cavagna et al., 2011).

Using the mixing curve with the UCDW and AZ-PF ML median values (Fig. 5a) and the following equation:

$f_{\mathrm{UCDW}}=\frac{\delta^{30} \mathrm{Si}_{\mathrm{AASW}}-\delta^{30} \mathrm{Si}_{\mathrm{ML}}}{\delta^{30} \mathrm{Si}_{\mathrm{UCDW}}-\delta^{30} \mathrm{Si}_{\mathrm{ML}}}$ 

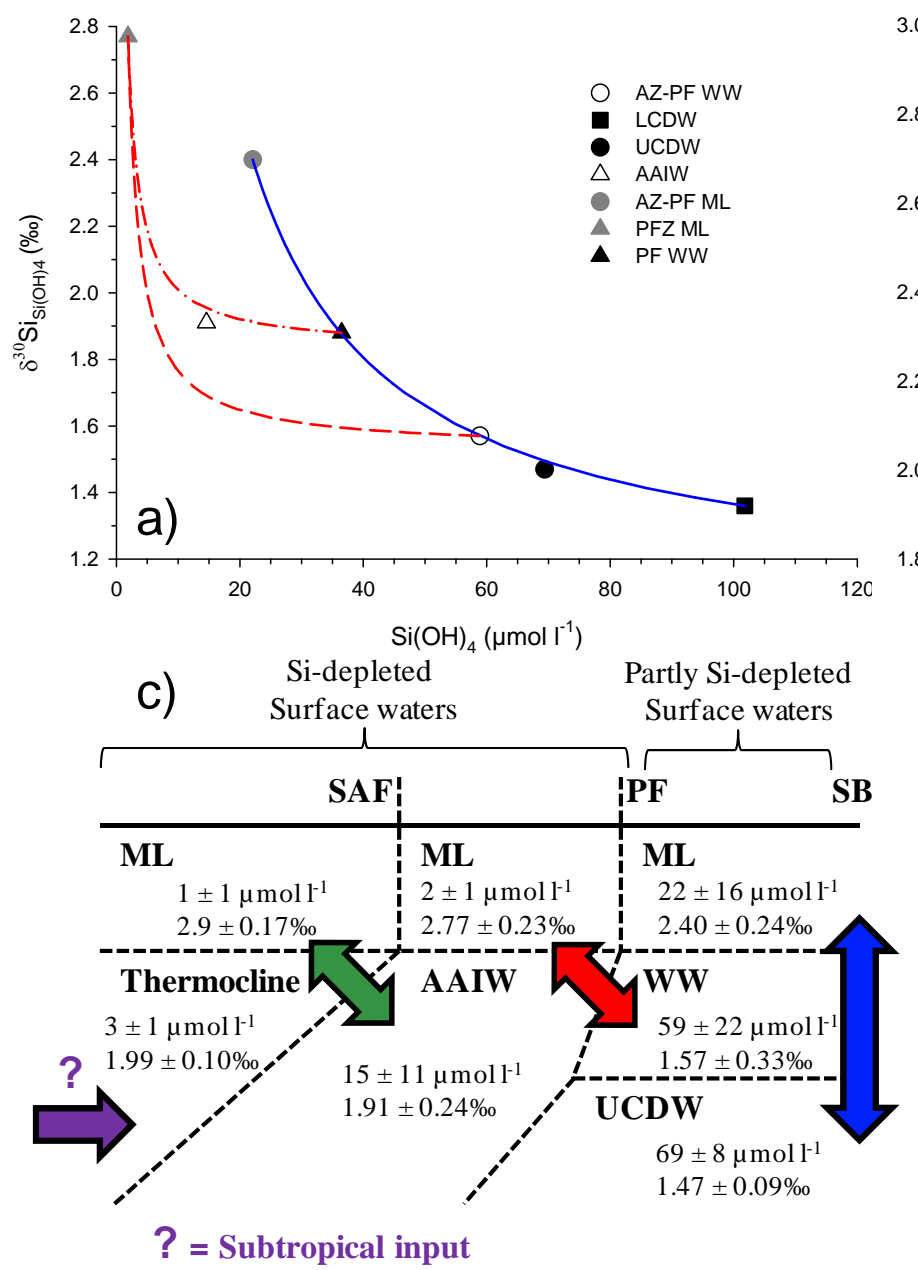

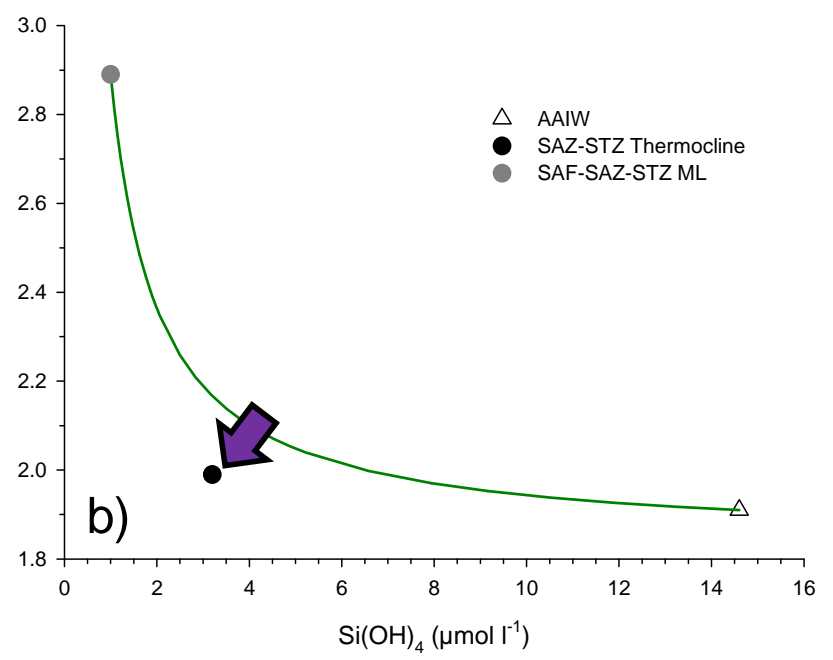

d)

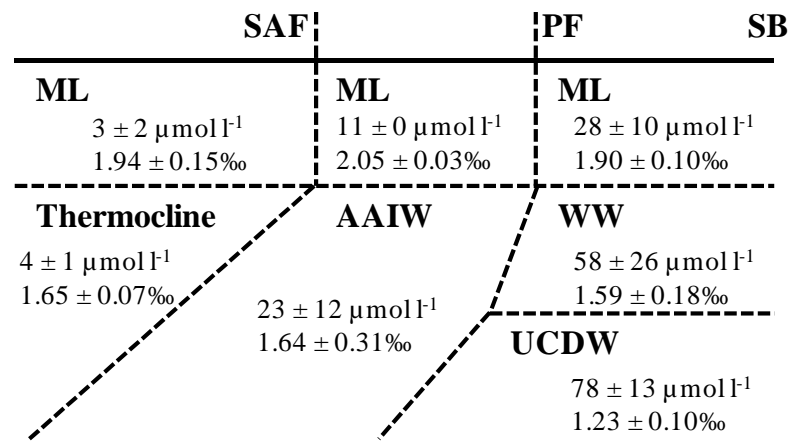

Fig. 5. (a) and (b): $\delta^{30} \mathrm{Si}$ and $\mathrm{Si}$ concentration values for different water masses across the BONUS-GoodHope transect (this study). Some mixing curve are also shown: between LCDW and AZ-PF mixed layer (blue line), between PF-AZ AASW and PFZ mixed layer (dashed red line), between PF AASW and PFZ mixed layer (dotted-dashed red line), and between AAIW and SAZ-STZ mixed layer (green line). When there is no indication of zone, it refers to the median of the whole BGH transect. (c): schematic view of the processes responsible for the observed $\delta^{30} \mathrm{Si}$ distribution in subsurface waters across BONUS-GoodHope north of the Southern Boundary, representing the mixing interfaces between surface and deeper waters. Identified mixing interfaces are the AASW = WW, the AAIW, and the low latitude thermoclines. The arrows represent the mixing end-members keeping the same colors than in (a) and (b). (d): schematic view of the mixing interfaces across the CLIVAR-SR3 transect north of the Southern Boundary (Cardinal et al., 2005). Median and interquartile range · 2/3 represent the "central value" and dispersion for the water masses. The number of computed data for BONUS Goodhope, respectively for $\mathrm{Si}(\mathrm{OH})_{4}$ and $\delta^{30} \mathrm{Si}_{\mathrm{Si}(\mathrm{OH}) 4}$, is for UCDW (24:24), WW (11:11), AAIW (11:11); STZ-SAZ thermocline (7:7); AZ-PF ML (8:8); PFZ ML (9:9); SAF-SAZ-STZ ML (6:5). For CLIVAR SR3, it is for UCDW (41:17), WW (12:8), AAIW (18:8), SAMW (11:3), AZ-PF ML (8:7); PFZ ML (4:2); SAF-SAZ-STZ ML (10:6).

we estimate the mean UCDW Si mass fraction contribution ( $\left.f_{\mathrm{UCDW}}\right)$ to AASW in the AZ (represented by the mean of AZ-PF WW) to be 0.89. This value is close to the values reported for: (1) the HNLC area east of the Kerguelen plateau with the same methodology (i.e. 0.78, Fripiat et al., 2011a); and (2) also at the $0^{\circ}$ Meridian between the SB and SACCF with a model using concentrations of nitrate and phosphates in winter (i.e. 0.90, Hoppema et al., 2000). By integrating the $\mathrm{WW} \mathrm{Si}(\mathrm{OH})_{4}$ concentration over the water column between the surface and bottom waters of the WW layer (i.e. the $300 \pm 50 \mathrm{~m}$ deep AASW) and multiplying that amount with the UCDW contribution, we calculate that UCDW contributes $15.7 \pm 2.6 \mathrm{~mol} \mathrm{Si} \mathrm{m}^{-2}$ to AASW. Standard errors for the mass balance estimations were obtained from Montecarlo simulations (normal distribution, $n=1000$ ). The $100 \pm 25 \mathrm{~m}$ deep summer ML will thus inherit $(100 / 300) \cdot\left(15.7 \pm 2.6 \mathrm{~mol} \mathrm{Si} \mathrm{m}^{-2}\right)$ or $5.2 \pm$ $1.3 \mathrm{~mol} \mathrm{Si} \mathrm{m}^{-2}$ which becomes available at the start of the growth season. The main assumptions behind these estimations are: (1) the UCDW Si-supply to the AASW mainly 
occurs during winter when the AASW is generated by deep convective mixing (Fig. 5a), and (2) the WW composition at the end of summer is still representative of the original AASW which represents the Si-source for the summer mixed layer (Pondaven et al., 2000a; Altabet and François, 2001; Fripiat et al., 2011a).

Assuming that steady state conditions apply (i.e. supply equals export at the annual scale), the effective annual net $\mathrm{bSiO}_{2}$ production should be equal to the annual vertical UCDW Si-supply of $5.2 \pm 1.1 \mathrm{~mol} \mathrm{Si} \mathrm{m}^{-2}$, which is again similar to the value of $4.0 \pm 0.7 \mathrm{~mol} \mathrm{Si} \mathrm{m}^{-2}$ we reported earlier for the Indian sector (Fripiat et al., 2011a). This value exceeds the seasonal depletion estimated from a simple mixed layer mass balance which is $3.6 \pm 0.9 \mathrm{~mol} \mathrm{Si} \mathrm{m}^{-2} \mathrm{yr}^{-1}$ (i.e. difference between $\mathrm{WW}$ and $\mathrm{ML} \mathrm{Si}(\mathrm{OH})_{4}$ concentration). Such imbalance indicates that some $1.6 \pm 0.4 \mathrm{~mol} \mathrm{Si} \mathrm{m}^{-2} \mathrm{yr}^{-1}$ are being supplied to the mixed layer during the summer stratification period. This flux is indistinguishable from the one observed in the Indian sector (Fripiat et al., 2011a). Sokolov and Rintoul (2007) stress the homogenous character of biogeochemical properties within the different ACC zones. Therefore, the discrepancy between net $\mathrm{bSiO}_{2}$ production and seasonal $\mathrm{Si}(\mathrm{OH})_{4}$ depletion is likely matched by a vertical supply of $\mathrm{Si}$, rather than a horizontal supply, which would advect waters with similar Si-conditions. Note that Hoppema et al. (2000) estimate also at $0^{\circ}$ meridian a seasonal silicic acid depletion, between the SACCF and SB, at $4.5 \pm 0.7 \mathrm{~mol} \mathrm{Si} \mathrm{m}^{-2} \mathrm{yr}^{-1}$. The slightly higher value from the latter study is probably due to the fact that this estimation has been done in the Southern AZ instead of the whole AZ.

Jin et al. (2006) estimated opal export out of the euphotic layer in the Southern Ocean in the range of 1 to $9 \mathrm{~mol} \mathrm{Si} \mathrm{m}^{-2} \mathrm{yr}^{-1}$, which encompasses our estimate of net $\mathrm{bSiO}_{2}$ production. Integrating our estimation over the whole $\mathrm{AZ}$ area $\left(14.10^{6} \mathrm{~km}^{2}\right.$, JGOFS synthesis report, 2001), net $\mathrm{bSiO}_{2}$ production is $73 \pm 18 \mathrm{Tmol} \mathrm{Si} \mathrm{yr}^{-1}$ including $22 \pm$ $5 \mathrm{Tmol} \mathrm{Si} \mathrm{yr}^{-1}$ originating from silicon supply during summer months. Considering a global net biogenic silica production of $171 \pm 35 \mathrm{Tmol} \mathrm{Si} \mathrm{yr}^{-1}$ (mean from Nelson et al., 1995; Usbeck, 1999; Heinze et al., 2003; Jin et al., 2006), the AZ therefore contributes $42 \pm 13 \%$ to this net production.

\subsubsection{Northern ACC and STZ}

The northern ACC is defined here as the area north of the PF and includes the STZ, although the latter is not normally considered part of ACC. The subsurface waters in the PFZ (halocline) fall on a mixing curve between the PF-AZ AASW and PFZ-PF ML (Fig. 6a). The subsurface layers in the PFZ could be a precursor of AAIW, spreading and deepening northwards through mesoscale frontal circulation (i.e. via meanders and eddies; Arhan et al., 2011). In this sector of the Southern Ocean, AAIW-type waters were observed north of the SAF (salinity minimum layer, $\sim 500$ to $1000 \mathrm{~m}$ ), these are
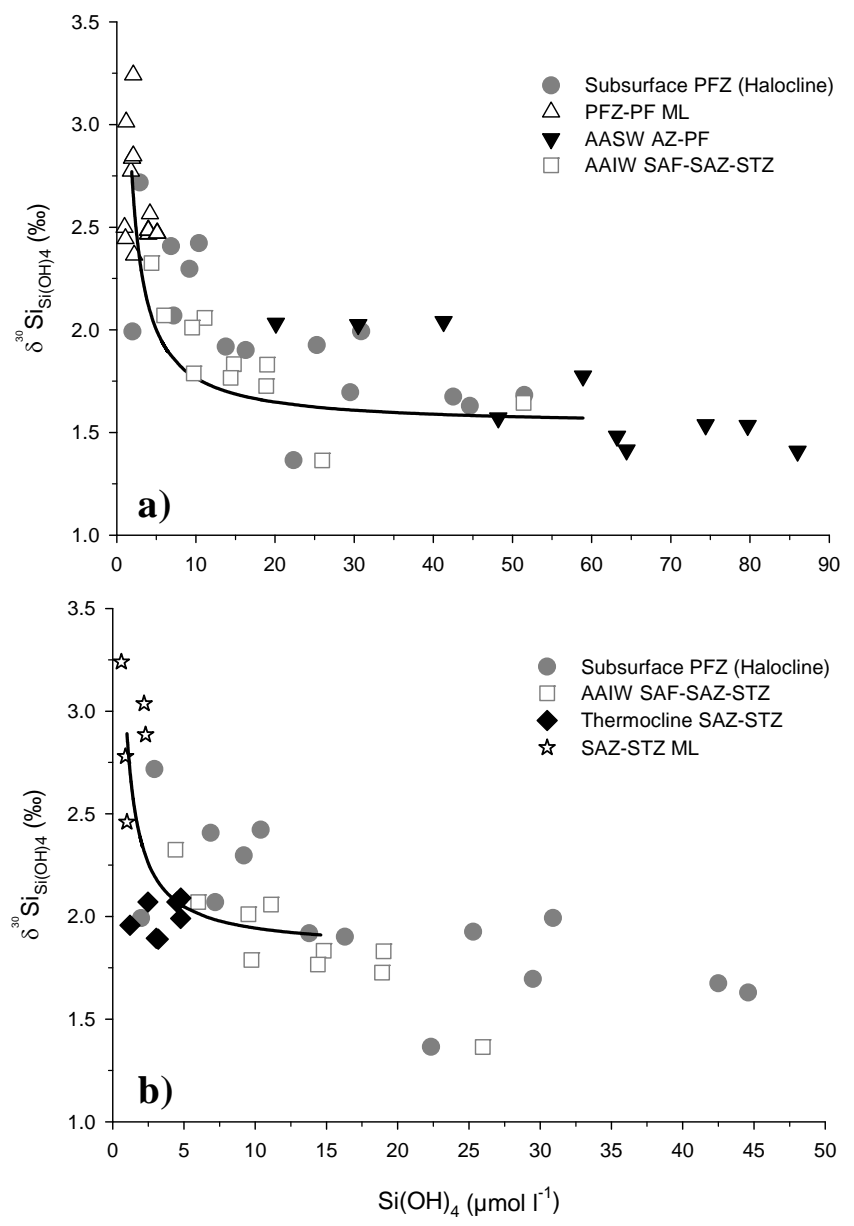

Fig. 6. (a): mixing curve between AZ-PF WW and PFZ-PF ML (black line). (b): mixing curve between STZ-SAZ mixed layer and AAIW. The end-members are estimated taking the median values for the considered water masses.

mainly of an Indian Ocean origin (Reid, 2003). Nevertheless, the AAIW north of the SAF is not significantly different from the PFZ subsurface waters in terms of Si-properties (t-test, $p$ value $>0.3$, both for concentration and isotopic composition; Fig. 6a). This could reflect the occurrence of similar formation dynamics such as mixing of AASW with highly Sidepleted mixed layers to the north. Whereas the involvement of AASW in the formation of AAIW is well established, the exact mechanisms are still unclear (Molinelli, 1981; England et al., 1993; Sloyan and Rintoul, 2001; Morrow et al., 2004). However, Tomczak and Godfrey (2001) conclude that both circumpolar cross-frontal mixing and PFZ local deep convective mixing play a role, which is in agreement with results published here.

The fact that the central value of AAIW falls off the mixing curve between the AZ-PF AASW (= AZ-PF WW) and PFZ ML end-members (Fig. 5a), may reflect that the AZPF AASW is not representative of AASW flowing into the PFZ via cross frontal exchanges. However, when selecting 
strictly the AASW (= PF WW), with Si-properties at the PF as end-member conditions, AAIW does fall on the mixing curve with PFZ-ML. Therefore PF AASW is a better endmember representative of the cross frontal exchange process.

We estimate the AASW Si mass fraction contribution to AAIW to reach 0.97 (adapted Eq. 2). Such a high value highlights that almost all the $\mathrm{Si}$ in the AAIW originates from the AASW layer with only a very low residual $\mathrm{Si}$ contribution from the summer PFZ mixed layers. Assuming steady state conditions once more, the annual AASW Sisupply into the AAIW must be balanced by the net $\mathrm{bSiO}_{2}$ production. Considering that the thickness of the AAIW and the ML layers are $750 \pm 250 \mathrm{~m}$ and $80 \pm 20 \mathrm{~m}$ (based on T-S water properties), respectively, we calculate the net $\mathrm{bSiO}_{2}$ production at $1.1 \pm 0.4 \mathrm{~mol} \mathrm{Si} \mathrm{m}^{-2} \mathrm{yr}^{-1}$. The seasonal Sidepletion (from the difference between AAIW and PFZ ML $\mathrm{Si}(\mathrm{OH})_{4}$ concentrations) is $1.0 \pm 0.3 \mathrm{~mol} \mathrm{Si} \mathrm{m}^{-2} \mathrm{yr}^{-1}$. This value is close to the net $\mathrm{bSiO}_{2}$ production estimate implying the summer Si-supply to be small and poorly constrained $\left(0.1 \pm 0.5 \mathrm{~mol} \mathrm{Si} \mathrm{m}^{-2} \mathrm{yr}^{-1}\right)$. Based on the compilation of Siuptake and $\mathrm{bSiO}_{2}$ dissolution rates from tracer incubation experiments, Fripiat et al. (2011b) noted that the mean net $\mathrm{bSiO}_{2}$ production in the PFZ was $1.2 \mathrm{~mol} \mathrm{Si} \mathrm{m}^{-2} \mathrm{yr}^{-1}$, in accordance with results published here. Integrating our estimation, $1.1 \pm 0.4 \mathrm{~mol} \mathrm{Si} \mathrm{m}^{-2} \mathrm{yr}^{-1}$, over the whole PFZ area $\left(3.10^{6} \mathrm{~km}^{2}\right.$, JGOFS synthesis report, 2001), the net $\mathrm{bSiO}_{2}$ production is $3 \pm 1 \mathrm{Tmol} \mathrm{Si} \mathrm{m}^{-2} \mathrm{yr}^{-1}$ representing $2 \pm 1 \%$ of the global net biogenic silica production (Nelson et al., 1995; Usbeck, 1999; Heinze et al., 2003; Jin et al., 2006). Thus diatom activity in the PFZ removes only a small fraction of the $\mathrm{Si}$ supplied to this area. The lower $\mathrm{Si}(\mathrm{OH})_{4}$ concentration of AAIW mainly reflect the highly $\mathrm{Si}(\mathrm{OH})_{4}$ depleted $\mathrm{PF}$ and PFZ surface water, imposing low $\mathrm{Si}(\mathrm{OH})_{4}$ contents on the resulting mixing product (AAIW) without inducing changes in $\delta^{30} \mathrm{Si}$ (Figs. 5a, c, 6).

Analysing the nitrate isotopic distribution, Sigman et al. (1999) suggested that the main source for nitrate in the PFZ was AASW advected northwards by Ekman drift. They report the AAIW to be only slightly different from AASW in terms of $\mathrm{NO}_{3}$ concentration and isotopic composition, which contrasts with our observations for $\mathrm{Si}$, especially regarding $\mathrm{Si}(\mathrm{OH})_{4}$ concentration, which is significantly lower in AAIW than in AASW. The large decoupling between the seasonal depletion of $\mathrm{Si}(\mathrm{OH})_{4}$ and nitrate in the mixed layer could explain the difference between this study and Sigman et al. (1999) regarding the degree of AASW alteration during formation of AAIW. Nitrate concentration is still high at the PF and PFZ (30 to $20 \mu \mathrm{mol} \mathrm{l}^{-1}$ ) compared to [Si(OH) $\left.)_{4}\right]$ $\left(<5 \mu \mathrm{moll}^{-1}\right)$, while Si and N contents of PF WW are both $\sim 35 \mu \mathrm{mol} 1^{-1}$. As a result, nitrate biogeochemical properties of AAIW appear closer to those for AASW, leading Sigman et al. (1999) to conclude that unaltered AASW is the main source for the AAIW nitrate pool.

The subsurface waters in SAZ and STZ are characterized by a thermocline between the mixed layer and the AAIW be-

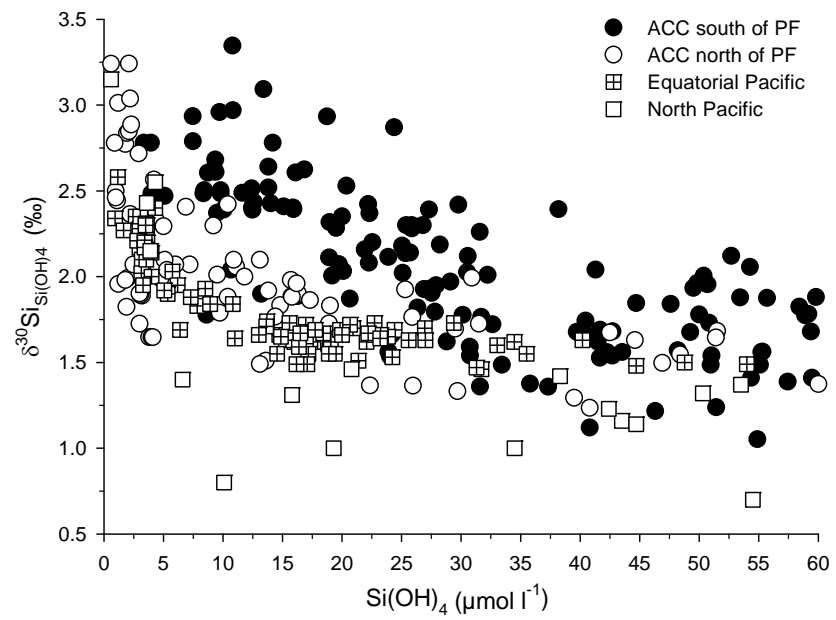

Fig. 7. $\delta^{30} \mathrm{Si}$ vs. $\mathrm{Si}(\mathrm{OH})_{4}$ for samples with $\mathrm{Si}<60 \mu \mathrm{mol} \mathrm{Si} 1^{-1}$ in the ACC and the Pacific Ocean: ACC south of the PF are represented by black dots (Varela et al., 2004; Cardinal et al., 2005; Fripiat et al., 2011c; Cavagna et al., 2011; this study), ACC north of the PF by white dots (Cardinal et al., 2005; this study), the Equatorial Pacific by crossed white squares (Beucher et al., 2008), and the north Pacific by white squares (De La Rocha et al., 2000; Reynolds et al., 2006).

low (salinity minimum layer). Despite the fact that values fall slightly below the mixing curve (Figs. $5 b$ and $6 b$ ), the Si characteristics clearly identify the thermocline in the SAZ and STZ as being a mixing interface between AAIW and the SAZ-STZ ML (Fig. 6b). The slight offset could be explained by the fact that the entire subtropical region, just north of our representative SAZ station (S2; Fig. 1a), is impacted by the Agulhas Current. This is the western boundary current flowing southward along the Southern Eastern Africa continental slope before retroflecting eastward and forming intense anticyclonic eddies (Agulhas rings), constituting the STF in the Indo-Atlantic sector and potentially crossing the STF into the SAZ region (Dencausse et al., 2011). These rings supply Indian central waters and AAIW of Indian origin into this region. Since the variety of the mixing end-members was not sampled here, it is not possible to estimate the net $\mathrm{bSiO}_{2}$ production and the summertime Si-supply as has been possible for the PFZ and the AZ.

The spreading and deepening northward of the Southern Ocean water masses (AAIW and SubAntarctic Mode Water (SAMW), the latter water mass was measured during CLIVAR-SR3 although not $\mathrm{BGH}$ ) is propagated towards the Equatorial Pacific, as clearly seen from their similarity with the $\mathrm{Si}$ isotopic composition of subsurface waters in the Equatorial Pacific (Beucher et al., 2008, Fig. 7). This indicates that AAIW-SAMW waters are the main Si-suppliers to the surface waters at lower latitudes, as has also been shown by Sarmiento et al. (2004). 


\subsubsection{Paleoceanographic implications}

The fact that the mesopelagic layers $(\sim 100-1000 \mathrm{~m})$ with their Si content and isotopic characteristics are the source region for Si to most of the surface waters, has significant implications for the paleoceanographic interpretation of the $\delta^{30} \mathrm{Si}$ records preserved in the sediments. Different ACC mixing interfaces have been identified: AASW, AAIW, both characterizing the halocline and the thermocline water northwards. The residual silicic acid concentrations of the endmembers control the $\delta^{30} \mathrm{Si}$ alteration of the mixing products. Except for AASW, all the mixing interfaces have a highly Sidepleted mixed layer as end-member. As a result, the silicic acid AASW concentration is diluted across the different interfaces without significantly changing the AASW $\delta^{30} \mathrm{Si}$ signature (Figs. 5c, 7). Si-utilization in the northern ACC and at lower latitudes will thus yield a similar surface water $\delta^{30} \mathrm{Si}$ range as in the southern ACC, although with a lower silicic acid concentration (Figs. 5c, 7). The North Pacific Ocean has significantly lighter $\delta^{30} \mathrm{Si}$ values (Reynolds et al., 2006) and consequently, for similar levels of Si-utilization, the $\delta^{30} \mathrm{Si}$ of the resulting surface water will be lighter. From a palaeoceanographic perspective, the mesopelagic variation in $\delta^{30} \mathrm{Si}$ recorded in the Southern ACC (within and south of the PF) induces a complexity since glacial circulation and hydrology is expected to be different from today (Toggweiler et al., 2006; Watson and Naveira Garabato, 2006). It is probable that different oceanic circulations altered the $\mathrm{Si}$ - properties of water masses and subsequently the $\delta^{30} \mathrm{Si}$ of the source regions feeding surface waters. $\delta^{30} \mathrm{Si}$ in the subsurface varies between +1.3 to $+2.0 \%$ o (Fig. $3 \mathrm{~b}, \mathrm{~d}$ ), a range which is significant with regard to the isotopic difference observed for Southern Ocean sediments between glacial/interglacial periods $(\sim+0.2$ to $+1.5 \%$ in the AZ, De La Rocha et al., 1998; Brzezinski et al., 2002, and $\sim+1$ to $+2 \%$ in the SAZ, Beucher et al., 2007). These dynamic effects must be assessed through, for example, a process-oriented modelling effort.

\subsection{Inter-oceanic leakage of Si-isotopes}

Along the pathway of the global ocean overturning circulation (OC), silicic acid concentrations increase in North Atlantic Deep Waters (NADW) during the processes of the OC towards the North Pacific and North Indian as the North Pacific Deep Water (NPDW) and the Indian Ocean Deep Water (IODW), respectively (Fig. 8a). This leads to a progressive accumulation of dissolved $\mathrm{Si}$ from $\mathrm{bSiO}_{2}$ dissolution (Sarmiento et al., 2004, 2007), which is supported by the differing values of the $\delta^{30} \mathrm{Si}$ of silicic acid which decreases from $\sim+1.4 \%$ in NADW to $\sim+0.6 \%$ in NPDW (Fig. $8 \mathrm{a}$; De La Rocha et al., 2000; Reynolds et al., 2006). Similar trends are also observed for $\delta^{13} \mathrm{C}_{\mathrm{DIC}}$ due to the remineralization of organic matter (Kroopnick, 1985). However, the lack of a $\delta^{30} \mathrm{Si}$ gradient between the NADW and Circumpolar Deep
Waters (CDW, Fig. 8a) probably results from an almost complete utilisation of silicic acid in most of the Atlantic Ocean surface waters (Conkright et al., 2002). As a result, the integrated $\delta^{30} \mathrm{Si}$ of sinking biogenic silica converges to the one of the source, i.e. silicic acid supply, so that the $\delta^{30} \mathrm{Si}$ of the $\mathrm{bSiO}_{2}$ rain-out from the surface is similar to that of silicic acid in subsurface waters (initially mostly AAIW), ultimately sinking in the North Atlantic to form NADW (Sarmiento et al., 2004; Reynolds, 2009). The subsequent Si-isotopic lightening from the CDW to the NPDW (Fig. 8a) can be attributed to the dissolution of settling diatoms in areas where silicic acid is only partly used (Pondaven et al., 2000b; Brzezinski et al., 2001). Consequently values integrate $\delta^{30} \mathrm{Si}$ signatures significantly lighter than the source, as is the case for the Southern Ocean and North Pacific. In contrast with Reynolds (2009) who, based on modelling approaches, reports that the Si isotopic gradient is centered in the Southern Ocean deep waters, the measured isotopic gradient in deep waters $(\sim 1.0 \%)$ is in fact sharper along the deep Pacific basins, while the isotopic shift observed along the ACC pathway shows only a slight, though significant (t-test, $p$ value $<0.001){ }^{30} \mathrm{Si}$ depletion of $\sim 0.2 \%$ (Fig. $8 \mathrm{~b}$ ).

Toggweiler et al. (2006) partitioned the global ocean's overturning circulation in two cells, the northern and southern cells which occupy distinct domains in the ocean's interior as detailed in the following. In the modern Ocean these cells mix together to form CDW, which comes up to the surface along the southern flank of the ACC. The middepth northern cell is the domain of North Atlantic Deep Water (NADW), presenting lower $\mathrm{Si}(\mathrm{OH})_{4}$ concentrations and heavier $\delta^{30} \mathrm{Si}$ values (Fig. 8a). The lower ventilated southern cell is the domain of the deep, bottom waters (AABW, IODW, and NPDW), characterised by higher $\mathrm{Si}(\mathrm{OH})_{4}$ concentrations and lighter $\delta^{30} \mathrm{Si}$ values (Fig. 8a). This partioning could partly explain the isotopic gradient in the CDW via isopycnal mixing from the Atlantic sector, where NADW enters the Southern Ocean, compared to the Australian sector, where waters are already potentially affected by the mixing with the IODW (Reid, 2003), probably bearing a lighter Siisotopic composition as for NPDW. Moreover, the partitioning of the global ocean's overturning circulation in two cells, with different ventilation rates (Toggweiler et al., 2006), could act as a positive feedback for the isotopic expression of biogenic silica dissolution effects in the Pacific Ocean as light silicic acid from $\mathrm{bSiO}_{2}$ dissolution is trapped in the $\mathrm{Pa}-$ cific Ocean, presenting lower ventilation (Sarmiento et al., 2007).

An unexpected feature is the much heavier isotopic composition in the eastern Equatorial Pacific and in the Cascadia basin (Beucher et al., 2008), compared to the western northern Pacific (Fig. 8a; De La Rocha et al., 2000; Reynolds, 2009). It is evident that more data from the deep Pacific and Indian Oceans are required in order to resolve the deep Siisotope distribution pattern and to identify the mechanisms driving it. 

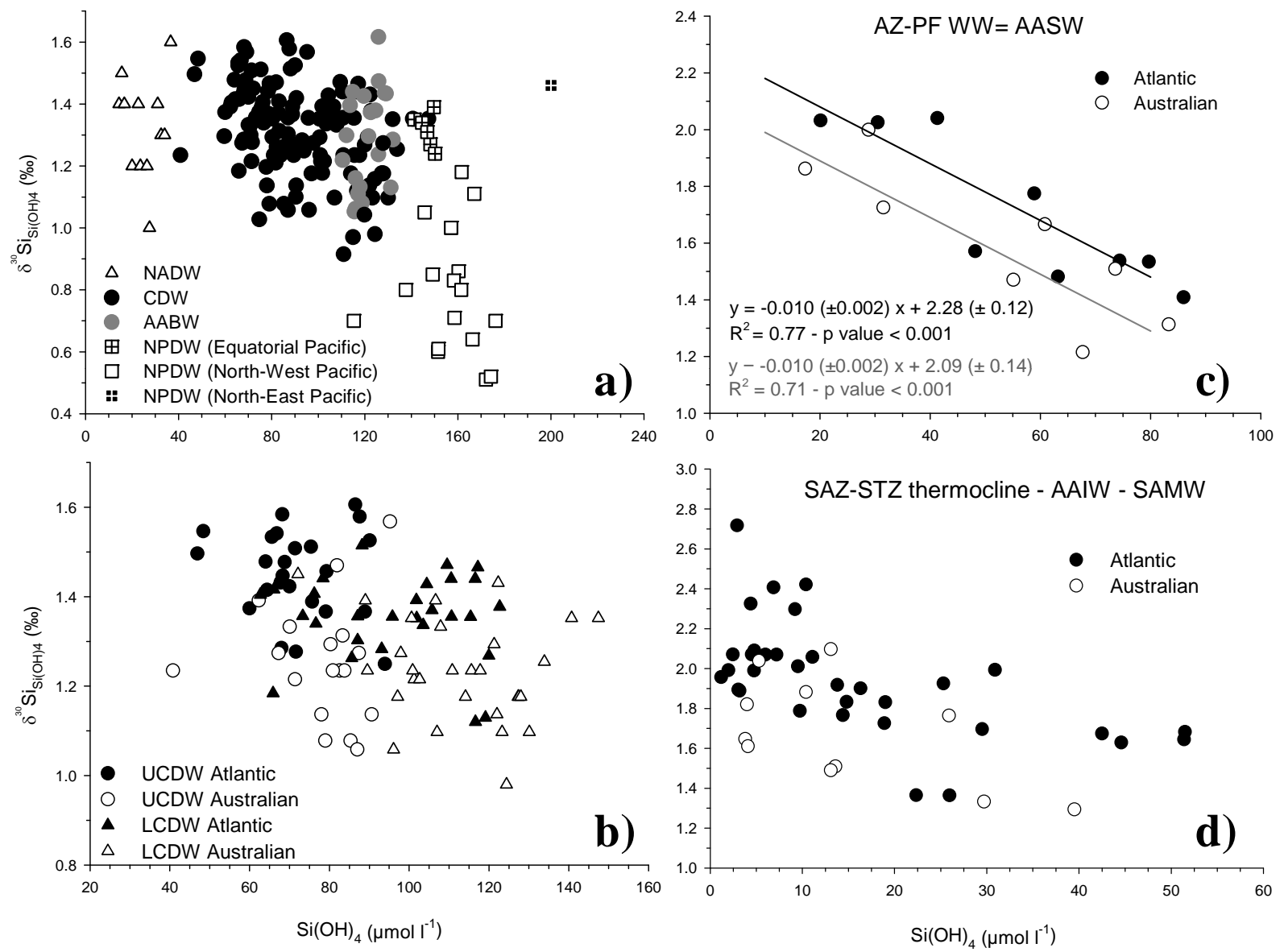

Fig. 8. (a): deep water distribution in the different oceanic basins: NADW (De La Rocha et al., 2000), CDW (Cardinal et al., 2005; this study), AABW (Cardinal et al., 2005; this study), NPDW (De La Rocha et al., 2000; Reynolds et al., 2006; Beucher et al., 2008). (b): CDW distribution for the Atlantic and Australian sectors, respectively this study and Cardinal et al. (2005). (c): AZ-PF WW = AASW distribution for the Atlantic and Australian sectors, respectively this study and Cardinal et al. (2005). (d): SAZ-STZ thermoclines, AAIW, and SAMW for the Atlantic and Australian sectors, respectively this study and Cardinal et al. (2005).

The isotopic gradient in deep waters, along the global overturning circulation, also seems to be expressed in the ${ }^{30} \mathrm{Si}$ values in the ACC subsurface waters between the Atlantic and the Australian sectors. Indeed, WW which is representative of winter AASW (Sect. 4.3) also displays a Siisotopic composition getting lighter from the Atlantic to the Australian sector (Fig. 8c; regression lines with the same slope (Mann-Whitney Rank Sum Test, $p$-value $=0.331$ ) but significantly different y-intercept (Mann-Whitney Rank Sum Test, $p$-value $<0.001$ ) as observed for the AAIW, the SAMW, and the SAZ-STZ thermoclines (Fig. 8d; t-test, $p$ value $=0.011$ ). If these trends are confirmed by a larger data set, they are to be taken into account when interpreting sedimentary archives and require the use of an appropriate correction factor. There is also need to further verify whether the observed trend in isotopic compositions can be confirmed along the ACC pathway in the Pacific.

\section{Conclusions}

This manuscript provides the first summer isotopic compositions of silicic acid $\left(\delta^{30} \mathrm{Si}\right)$ across the whole ACC and adjacent subsystems, the SubTropical Zone and the Weddell Gyre, for the full-depth water column in the Atlantic sector.

In a similar way as reported in Fripiat et al. (2011a), we used the Si-isotopic constraint to assess (1) net $\mathrm{bSiO}_{2}$ production and (2) summertime Si-supply into the mixed layer: estimated at (1) $5.2 \pm 1.3$ and $1.6 \pm 0.4 \mathrm{~mol} \mathrm{Si} \mathrm{m}^{-2}$ and (2) $1.1 \pm 0.3$ and $0.1 \pm 0.5 \mathrm{~mol} \mathrm{Si} \mathrm{m}^{-2}$, respectively for the mean Antarctic Zone and Polar Front Zone. These results are within the range of other published data. Integrating our estimation over the whole AZ and PFZ area (JGOFS synthesis report, 2001), the net $\mathrm{bSiO}_{2}$ production contributes $42 \pm 13$ and $2 \pm 1 \%$ respectively, to the global net biogenic silica production of $171 \pm 35 \mathrm{Tmol} \mathrm{Si} \mathrm{yr}^{-1}$ (Nelson et al., 1995; Usbeck, 1999; Heinze et al., 2003; Jin et al., 2006). 
$\delta^{30} \mathrm{Si}$ in the subsurface waters is mainly controlled by mixing processes, transmitting the isotopic imprint resulting from surface water Si-uptake down to depth. Different mixing interfaces have been determined: the Antarctic Surface Water, the Antarctic Intermediate Water, and the low latitude thermoclines. The level of Si-depletion is an important factor controlling the alteration of $\delta^{30} \mathrm{Si}$ in the mixing interface. Indeed, a highly Si-depleted water mass dilutes the silicic acid concentration of the mixing product, without significantly affecting $\delta^{30} \mathrm{Si}$. Except for the AASW, which is the ultimate source for the subsurface waters in the ACC, each mixing interface has a highly depleted mixed layer as an end-member. Overall the AASW silicic acid concentration strongly decreases northward across the different mixing interfaces, keeping the initial AASW $\delta^{30} \mathrm{Si}$ signature (Cardinal et al., 2005; Beucher et al., 2008; this study). Consequently, almost all surface waters in the modern ocean within and north of the PF are characterised by similar $\delta^{30} \mathrm{Si}$ signatures, though silicic acid concentrations differ. Such observations contrast significantly with the model outputs from Wischmeyer et al. (2003) or Reynolds (2009), and point out the absence of knowledge of the processes involved in modern Si-isotopic distributions.

Ocean hydrology and circulation is thought to be different along glacial/interglacial timescales. Modification of the ocean's circulation could therefore significantly affect the $\delta^{30} \mathrm{Si}$ of subsurface waters. Through a process-oriented modelling effort, this mixing induced variability in $\delta^{30} \mathrm{Si}$ has to be better constrained for the proper use of this proxy in paleoceanography. Furthermore, as has been highlighted here, a progressive decrease in $\delta^{30} \mathrm{Si}$ values is observed along the eastward ACC transport of water masses between the Atlantic (this study) and the Australian sector (Cardinal et al., 2005). This probably results from: (1) the progressive accumulation of $\mathrm{Si}$ from dissolving biogenic silica along the eastward ACC transport and (2) isopycnal mixing between deep water masses in each of the oceanic basins. Should this ACC trend be further confirmed by new Pacific ACC transects, this isotopic effect would then need to be corrected when the isotopic composition of sedimentary biogenic silica is interpreted.

Acknowledgements. Our warm thanks go to the officers and crew of the R/V Marion Dufresne during the BONUS-GoodHope program and the Institut Paul Emile Victor for inviting us on board. We are also grateful to J. de Jong and N. Mattielli for the management of the MC-ICP-MS laboratory at ULB and to L. Monin and N. Dahkani (RMCA) for their help in sample processing and to Virginia Panizzo (ULB) for correction of English. This work was conducted within the BELCANTO III network (contracts SD/CA/03A of SPSDIII, Support Plan for Sustainable Development) funded by BELSPO, the Belgian Science Policy. Luc André thanks the FNRS for its financial support (FRFC project 2.4512.00). F. Fripiat is a postdoctoral fellow funded by the FNRS.
Edited by: M. Hoppema

\section{References}

Abraham, K., Opfergelt, S., Fripiat, F., Cavagna, A.-J., de Jong, J. T. M., Foley, S. F., André, L., and Cardinal, D.: $\delta^{30} \mathrm{Si}$ and $\delta^{29} \mathrm{Si}$ determinations on USGS BHVO-1 and BHVO-2 reference materials with a new configuration on a Nu Plasma Multi-Collector ICP-MS, Geost. Geoanal. Res., 32(2), 193-202, 2008.

Alleman, L., Cardinal, D., Cocquyt, C., Plisnier, P. D., Descy, J.-P., Kimirei, I., Sinyinza, D., and André, L.: Silicon isotopic fractionation in Lake Tanganyika and its main tributaries, J. Great Lakes Res. 31, 509-519, 2005.

Allison, D. B., Stramski, D., and Mitchell, B. G.: Seasonal and interannual variability of particulate organic carbon within the Southern Ocean from satellite ocean color observations, J. Geophys. Res. 115, C06002, doi:10.1029/2009JC005347, 2010.

Altabet, M. A. and François, R.: Nitrogen isotope biogeochemistry of the Antarctic Polar Frontal Zone at $170^{\circ} \mathrm{W}$, Deep-Sea Res. Pt. II, 48, 4247-4273, 2001.

Arhan, M., Speich, S., Messager, C., Dencausse, G., Fine, R., and Boye, M.: Anticyclonic and cyclonic eddies of subtropical origin in the subantarctic zone south of Africa, J. Geophys. Res., doi:10.1029/2011JC007140, in press, 2011.

Baines, S. B., Twining, B. S., Brzezinski, M. A., Nelson, D. M., and Fisher, N. S.: Causes and biogeochemical implications of regional differences in silicification of marine diatoms, Global Biogeochem. Cy., 24, GB4031, doi:10.1029/2010GB003856, 2010.

Beucher, C. P., Brzezinski, M. A., and Crosta, X.: Silicic acid dynamics in the glacial sub-Antarctic: Implications for the silicic acid leakage hypothesis, Global Biogeochem. Cy., 21, GB3015, doi:10.1029/2006GB002746, 2007.

Beucher, C. P., Brzezinski, M. A., and Jones, J. L.: Sources and biological fractionation of silicon isotopes in the Eastern Equatorial Pacific, Geochim. Cosmochim. Ac., 72, 3063-3073, 2008.

Branellec, P., Arhan, M., and Speich, S.: Projet GoodHope, Campagne BONUS-GoodHope, Rapport de données CTD-O2. Rapport interne Ifremer, OPS/LPO/10-02, LPO-IFREMER, 2010.

Brzezinski, M. A., Nelson, D. M, Franck, V. M., and Sigmon, D. E.: Silicon dynamics within an intense open-ocean diatom bloom in the Pacific sector of the Southern Ocean, Deep-Sea Res. Pt. II, 48, 3997-4018, 2001.

Brzezinski, M. A., Pride, C. J., Franck, V. M., Sigman, D. M., Sarmiento, J. L., Matsumoto, K., Gruber, N., Rau, G. H., and Coale, K. H.: A switch from $\mathrm{Si}(\mathrm{OH})_{4}$ to $\mathrm{NO}_{3}^{-}$depletion in the glacial Southern Ocean, Geophys. Res. Lett. 29(12), 1564, doi:10.1029/2001GL014349, 2002.

Brzezinski, M. A., Dickson, M.-L., Nelson, D. M., and Sambrotto, R.: Ratios of Si, C and N uptake by microplankton in the Southern Ocean, Deep-Sea Res. Pt. II, 50, 619-633, 2003 a.

Brzezinski, M. A., Jones, J. L., Bidle, K. D, and Azam, F.: The balance between silica production and silica dissolution in the sea: Insights from Monteray Bay, California, applied to the global data set, Limnol. Oceanogr., 48(5), 1846-1854, 2003 b.

Cardinal, D., Alleman, L. Y., de Jong, J., Ziegler, K., and André, L.: Isotopic composition of silicon measured by multicollector plasma source mass spectrometry in dry plasma mode, J. Anal. Atom. Spectrom., 18, 213-218, 2003. 
Cardinal, D., Alleman, L. Y., Dehairs, F., Savoye, N., Trull, T. W., and André, L.: Relevance of silicon isotopes to Si-nutrient utilization and Si-source assessment in Antarctic waters, Global Biogeochem. Cy., 19, GB2007, doi:10.1029/2004GB002364, 2005.

Cardinal, D., Savoye, N., Trull, T. W., Dehairs, F., Kopczynska, E. E., Fripiat, F., Tison, J.-L., and André, L.: Silicon isotopes in spring Southern Ocean diatoms: large zonal changes despite homogeneity among size fractions, Mar. Chem., 106, 46-62, 2007.

Cavagna, A.-J., Fripiat, F., Dehairs, F., Wolf-Gladrow, D., Cisewski, B., Savoye, N., André, L., and Cardinal, D.: Silicon uptake and supply during a Southern Ocean iron fertilization experiment (EIFEX) tracked by Si isotopes, Limnol. Oceanogr., 56(1), 147160, 2011.

Conkright, M. E., Locarnini, R. A., Garcia, H. E., O’Brien, T. D., Boyer, T. P., Stephens, C., and Antonov, J. I.: World Ocean Atlas 2001; Ojective Anlyses, Data Statistics, and Figures, CD-ROM Documentation, Natl. Oceanogr. Data Cent., Silver Spring, Md, 2002.

De La Rocha, C. L., Brzezinski, M. A., and DeNiro, M. J.: Purification recovery and laser-driven fluorination of silicon from dissolved and particulate silica for the measurement of natural stable isotope abundances, Anal. Chem., 68, 3746-3750, 1996.

De La Rocha, C. L., Brzezinski, M. A., and DeNiro, M. J.: Fractionation of silicon isotopes by marine diatoms during biogenic silica formation, Geochim. Cosmochim. Ac., 61(23), 5051-5056, 1997.

De La Rocha, C. L., Brzezinski, M. A., and DeNiro, M. J.: Siliconisotope composition of diatoms as an indicator of past oceanic change, Nature, 395, 680-683, 1998.

De La Rocha, C. L., Brzezinski, M. A., and DeNiro, M. J.: A first look at the distribution of the stable isotopes of silicon in natural waters, Geochim. Cosmochim. Ac., 64(14), 2467-2477, 2000.

Demarest, M. S., Brzezinski, M. A., and Beucher, C. P.: Fractionation of silicon isotopes during biogenic silica dissolution, Geochim. Cosmochim. Ac., 73, 5572-5583, doi:10.1016/j.gca.2009.06.019, 2009.

Dencausse, G., Arhan, M., and Speich, S.: Is there a continuous Subtropical Front south of Africa?, J. Geophys. Res. 116, C02027, doi:10.1029/2010JC006587, 2011.

Dugdale, R. C., Wilkerson, F. P., and Minas, H. J: The role of a silicate pump in driving new production, Deep-Sea Res. Pt. I, 42(5), 697-719, 1995.

England, M. H., Godfrey, J. S., Hirst, A. C., and Tomczak, M.: The mechanism for Antarctic Intermediate Water renewal in a world Ocean Model, J. Phys. Oceanogr., 23, 1553-1560, 1993.

Franck, V. M., Bruland, K. W., Hutchins, D. A., and Brzezinski, M. A.: Iron and zinc effects on silicic acid and nitrate uptake kinetics in three high-nutrient, low-chlorophyll (HNLC) regions, Mar. Ecol.-Prog. Ser., 252, 15-33, 2003.

Fripiat, F.: Isotopic approaches of the silicon cycle: The southern Ocean case study, Ph.D. thesis, Université Libre de Bruxelles, available at: http://theses.ulb.ac.be/ETD-db/collection/available/ ULBetd-12142009-190405/, 2010.

Fripiat, F., Cavagna, A.-J., Savoye, N., Dehairs, F., André, L., and Cardinal, D.: Isotopic constraints on the Si-biogeochemical cycle of the Antarctic Zone in the Kerguelen area (KEOPS), Mar. Chem., 123, 11-22, 2011a.

Fripiat, F., Leblanc, K., Elskens, M., Cavagna, A.-J., Armand, L.,
André, L., Dehairs, F., and Cardinal, D.: Summer efficient silicon loop across the Polar Front and SubAntarctic Zones despite contrasted diatom Si-affinity, Mar. Ecol.-Prog. Ser., 435, 47-61, , 2011b.

Fripiat, F., Cavagna, A.-J., Dehairs, F., André, L., and Cardinal, D.: Processes controlling Si-isotopic composition in the Southern Ocean for an application in paleoceanography, Biogeosciences, in preparation, 2011c.

Grasshof, K., Erhardt, M., and Kremling, K.: Methods of seawater analysis, 2nd edn., Verlag Chemie, Weinheim, 1983.

Heinze, C., Hupe, A., Maier-Reimer, E., Dittert, N., and Ragueneau, O.: Sensitivity of the marine biospheric Si-cycle for biogeochemical parameter variations, Global Biogeochem. Сy. 17(3), 1086, doi:10.1029/2002GB001943, 2003.

Hoppema, M., Fahrbach, E., and De Baar, H. J. W.: Surface layer balance of the southern Antarctic Circumpolar Current (prime meridian) used to derive carbon and silicate consumptions and annual air-sea exchange for $\mathrm{CO}_{2}$ and oxygen, J. Geophys. Res., 105(C5), 11359-11371, doi:2000JC000257, 2000.

Jin, X., Gruber, N., Dunne, J. P., Sarmiento, J. L., and Amstrong, R. A.: Diagnosing the contribution of phytoplankton functional groups to the production and export of particulate organic carbon, $\mathrm{CaCO}_{3}$, and opal from global nutrient and alkalinity distributions, Global Biogeochem. Cy., 20, GB2015, doi:10.1029/2005GB002532, 2006.

Karl, D. M. and Tien, G.: MAGIC: a sensitive and precise method for measuring dissolved phosphorus in aquatic environments, Limnol. Oceanogr., 37(1), 105-116, 1992.

Kroopnick, P. M.: The distribution of ${ }^{13} \mathrm{C}$ of $\mathrm{TCO}_{2}$ in the world oceans, Deep-Sea Res., 32, 57-84, 1985.

Molinelli, E. T.: The Antarctic influence on Antarctic Intermediate Water, J. Mar. Res. 39, 267-293, 1981.

Moore, J. K. and Abbott, M. R.: Phytoplankton chlorophyll distributions and primary production in the Southern Ocean, J. Geophys. Res., 105(12), 28709-28722, 2000.

Morrow, R. A., Coleman, R., Church, J. A., and Chelton, D. B.: Surface eddy momentum flux and velocity variances in the Southern Ocean from geosat altimetry, J. Phys. Oceanogr., 24, 2050-2071, 2004.

Nelson, D. M., Tréguer, P., Brzezinski, M. A., Leynaert, A., and Quéguiner, B.: Production and dissolution of biogenic silica in the ocean: revised global estimates comparison with regional data and relationship to biogenic sedimentation, Global Biogeochem. Cy., 9(3), 359-372, 1995.

Orsi, A. H., Johnson, G. C., and Bullister, J. L.: Circulation, mixing, and production of Antarctic Bottom Water, Prog. Oceanogr. 43, 55-109, 1999.

Park, Y.-H., Charriaud, E., and Fieux, M.: Thermohaline structure of the Antarctic Surface Water/Winter Water in the Indian sector of the Southern Ocean, J. Marine Syst., 17, 5-23, 1998.

Pollard, R. T., Lucas, M. I., and Read, J. F.: Physical controls on biogeochemical zonation in the Southern Ocean, Deep-Sea Res., 49, 3289-3305, 2002.

Pollard, R. T., Tréguer, P., and Read, J.: Quantifying nutrient supply to the Southern Ocean, J. Geophys. Res., 111, C05011, doi:10.1029/2005JC003076, 2006.

Pondaven, P., Ragueneau, O., Tréguer, P., Hauvespre, A., Dezileau, L., and Reyss, J. L.: Resolving the "opal paradoxe" in the Southern Ocean, Nature, 466, 47-55, 2000a. 
Pondaven, P., Ruiz-Pino, D., Fravalo, C., Tréguer, P., and Jeandel, C.: Interannual variability of $\mathrm{Si}$ and $\mathrm{N}$ cycles at the timeseries station KERFIX between 1990 and 1995 - a 1-D modelling study, Deep-Sea Res. Pt. I, 47, 223-257, 2000 b.

Pondaven, P., Gallinari, M., Chollet, S., Bucciarelli, E., Sarthou, G., Schultes, S., and Jean, F.: Grazing-induced changes in cell wall silicification in a marine diatoms, Protist, 158, 21-28, 2007.

Reid, J. L.: On the total geostrophic circulation of the Indian Ocean: flow patterns, tracers, and transports, Prog. Oceanogr., 56, 137186, 2003.

Reynolds, B. C., Frank, M., and Halliday, A. N.: Silicon isotope fractionation during nutrient utilization in the North Pacific, Earth Planet. Sc. Lett., 244, 431-443, 2006.

Reynolds, B. C., Aggarwal, J., André, L., Baxter, D., Beucher, C., Brzezinski, M. A., Engström, E., Georg, R. B., Land, M., Leng, M. J., Opfergelt, S., Rodushkin, I., Sloane, H. J., van den Boorn, H. J. M., Vroon, P. Z., and Cardinal, D.: An inter-laboratory comparison of Si isotope reference materials, J. Anal. Atom. Spectrom., 22, 561-568, doi:10.1039/b616755a, 2007.

Reynolds, B. C.: Modeling the modern marine $\delta^{30} \mathrm{Si}$ distribution, Global Biogeochem. Cy., 23, GB2015, doi:10.1029/2008GB003266, 2009.

Sarmiento, J. L., Gruber, N., Brzezinski, M. A., and Dunne, J. P.: High-latitude controls of thermocline nutrients and low latitude biological productivity, Nature, 427, 56-60, 2004.

Sarmiento, J. L., Simeon, J., Gnanadesikan, A., Gruber, N., Key, R. M., and Schlitzer, R.: Deep ocean biogeochemistry of silicic acid and nitrate, Global Biogeochem. Cy., 21, GB1S90, doi:10.1029/2006GB002720, 2007.

Schultes, S., Lambert, C., Pondaven, P., Corvaisier, R., Jansen, S., and Ragueneau, O.: Recycling and Uptake of $\mathrm{Si}(\mathrm{OH})_{4}$ when Protozoan Grazers Feed on Diatoms, Protist, 161, 288-303, 2010.

Sigman, D. M., Altabet, M. A., McCorkle, D. C., François, R., and Fischer, G.: The $\delta^{15} \mathrm{~N}$ of nitrate in the Southern Ocean: Consumption of nitrate in surface waters, Global Biogeochem. Cy., 13, 1149-1166, 1999.

Sigman, D. M., Hain, M. P., and Haug, G. H.: The polar ocean and glacial cycles in atmospheric $\mathrm{CO}_{2}$ concentration, Nature, 466, 47-55, doi:10.1038/nature09149, 2010.

Sloyan, B. M. and Rintoul, S. R.: Circulation, renewal, and modification of Antarctic mode and intermediate water, J. Phys. Oceanogr., 31, 1005-1030, 2001.
Smetacek, V., Assmy, P., and Henjes, J.: The role of grazing in structuring Southern Ocean pelagic ecosystems and biogeochemical cycles, Antarct. Sci., 16, 541-558, 2004.

Sokolov, S. and Rintoul, S. R.: On the relationship between fronts of the Antarctic Circumpolar Current and surface chlorophyll concentration in the Southern Ocean, J. Geophys. Res., 112, C07030, doi:10.1029/2006JC004072, 2007.

Sokolov, S. and Rintoul, S. R.: Circumpolar structure and distribution of the Antarctic Circumpolar fronts: 1. Mean circumpolar path, J. Geophys. Res., 114, C11018, doi:10.1029/2008JC005108, 2009.

Speich, S., Arhan, M., Gladyshev, S., Rupolo, V., and Fine, R.: Structure and dynamics along the BONUS-GoodHope transect, Ocean Sci., in preparation, 2011.

Takeda, S.: Influence of iron availability on nutrient consumption ratio of diatoms in oceanic waters, Nature, 393, 774-777, 1998.

Toggweiler, J. R., Russell, J. L., and Carson, S. R.: Midlatitudes westerlies, atmospheric $\mathrm{CO}_{2}$, and climate change during the ice ages, Paleoceanography, 21, PA2005, doi:10.1029/2005PA001154, 2006.

Tomczak, M. and Godfrey, J. S.: Regional Oceanography: An Introduction, Pergamon, New York, 2001.

Usbeck, R.: Modeling of marine biogeochemical cycles with an emphasis on vertical particle fluxes, Ph.D. thesis, Univ. of Bremen, Bremen, Germany, 105 pp., 1999.

Varela, D. E., Pride, C. J., and Brzezinski, M. A.: Biological fractionation of silicon isotopes in Southern Ocean surface waters, Global Biogeochem. Cy., 18, GB1047, doi:10.1029/2003GB002140, 2004.

Watson, A. J. and Naveira Garabato, A. C.: The role of Southern Ocean mixing and upwelling in glacial-interglacial atmospheric $\mathrm{CO}_{2}$ change, Tellus, 58B, 73-87, 2006.

Wischmeyer, A. G., De La Rocha, C. L., Maier-Reimer, E., and Wolf-Gladrow, D. A.: Control mechanisms for the oceanic distribution of silicon isotopes, Global Biogeochem. Cy., 17(3), 1083, doi:10.1029/2002GB002022, 2003.

Young, E. D., Galy, H., and Nagahara, H.: Kinetic and equilibrium mass-dependent isotope fractionation laws in nature and their geochemical and cosmochemical significance, Geochim. Cosmochim. Ac., 66(6), 1095-1104, 2002. 